\title{
Study of genetic damage in the japanese oyster induced by an environmentally-relevant exposure to diuron: evidence of vertical transmission of dna damage
}

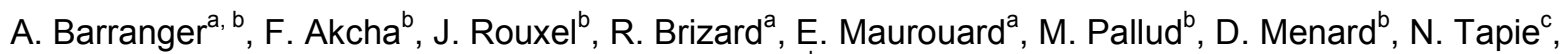 \\ H. Budzinski ${ }^{\mathrm{c}}, \mathrm{T}$. Burgeot ${ }^{\mathrm{b}}, \mathrm{A}$. Benabdelmouna ${ }^{\mathrm{a}}$
a Ifremer, SG2 M, Laboratory of Genetics and Pathology of Marine Molluscs, Avenue de Mus du Loup, F-17390 La Tremblade, France
${ }^{\mathrm{b}}$ Ifremer, Department of Biogeochemistry and Ecotoxicology, Laboratory of Ecotoxicology, Rue de I'lle d'Yeu, BP 21105, F-44311 Nantes Cedex 03, France
${ }^{c}$ Univ. Bordeaux, EPOC UMR CNRS 5805, F-33400 Talence, France

\begin{abstract}
:
Pesticides represent a major proportion of the chemical pollutants detected in French coastal waters and hence a significant environmental risk with regards to marine organisms. Commercially-raised bivalves are particularly exposed to pollutants, among them pesticides, as shellfish farming zones are subject to considerable pressure from agricultural activities on the mainland.

The aims of this study were to determine (1) the genotoxic effects of diuron exposure on oyster genitors and (2) the possible transmission of damaged DNA to offspring and its repercussions on oyster fitness. To investigate these points, oysters were exposed to concentrations of diuron close to those detected in the Marennes-Oleron Basin (two 7-day exposure pulses at 0.4 and $0.6 \mu \mathrm{g} \mathrm{L}^{-1}$ ) during the gametogenesis period. Genomic abnormalities were characterized using two complementary approaches. The Comet assay was applied for the measurement of early and reversible primary DNA damage, whereas flow cytometry was used to assess the clastogenic and aneugenic effect of diuron exposure. Polar Organic Chemical Integrative Samplers (POCIS) were used in exposed and assay tanks to confirm the waterborne concentration of diuron reached during the experiment.

The results obtained by the Comet assay clearly showed a higher level of DNA strand breaks in both the hemocytes and spermatozoa of diuron-exposed genitors. The transmission of damaged genetic material to gamete cells could be responsible for the genetic damage measured in offspring. Indeed, flow cytometry analyses showed the presence of DNA breakage and a significant decrease in DNA content in spat from diuron-exposed genitors. The transmission of DNA damage to the offspring could be involved in the negative effects observed on offspring development (decrease in hatching rate, higher level of larval abnormalities, delay in metamorphosis) and growth.

In this study, the vertical transmission of DNA damage was so highlighted by subjecting oyster genitors to short exposures to diuron at medium environmental concentrations. The analysis of POCIS showed that oysters were exposed to integrated concentrations as low as 0.2 and $0.3 \mu \mathrm{g} \mathrm{L}^{-1}$, emphasing the relevance of the results obtained and the risk associated to chemical contamination for oyster recruitment and fitness.
\end{abstract}

\section{Highlights}

Oyster genitors were exposed to environmental concentrations of diuron during gametogenesis. genotoxic effect was observed in hemocytes and spermatozoa of diuron-exposed genitors. DNA damage in spermatozoa could be involved in the negative effects observed on oyster recruitment. Vertical transmission of DNA damage was evidenced by DNA aneuploidy in spat from exposed genitors.

Keywords : Herbicide ; Diuron ; Oyster ; Genotoxicity ; Comet assay ; Cytogenetics 


\section{Introduction}

Coastal ecosystems are exposed to various forms of pollution from human activities. Over $80 \%$ of marine pollution comes from the mainland and originates from industrial, agricultural and urban activities (UNEP, 2004; SOES, 2011). France is the leading user of agrochemicals in Europe and the third in the World (Jacquet et al., 2011; UIPP, 2012). As a result of this high consumption of phytosanitary products, pesticides can contaminate coastal waters through various processes, including run-offs, leaching and spray drift. Some pesticides are notoriously toxic; indeed, out of the 41 priority substances identified by the EU Water Framework Directive (Directive 2008/105/EC), 14 are pesticides. Their presence in coastal waters is therefore a potential major environmental hazard for marine organisms.

The ecological characteristics of mollusks, and in particular bivalves and gastropods (filter feeders, sessile mode of life and ability to bioaccumulate pollutants), makes them highly sensitive to chemical stresses. They are therefore considered as reliable species for the study of pollutant effects in the marine environment (His et al., 1999). Moreover, the Pacific oyster Crassostrea gigas is one of the foremost aquaculture resources on a worldwide level (FAO, 2011). C.gigas has been farmed in France since the late 1970s. France is currently Europe's leading producer, with 82,800 metric tons in $2010 / 2011,20,000$ of which $(24 \%)$ were farmed in the Poitou-Charentes region alone (CNC, 2012). High mortality rates for this species have been observed in summer for several years; this phenomenon does not appear to be due to a single pathogenic cause, but a combination of several abiotic (physico-chemical environmental parameters, pollution and aquaculture practices) and biotic factors (e.g. pathogens and physiological status of the oyster) (Samain et al., 2007).

In the main French farming basins where Pacific oysters reproduce naturally, flow cytometry analysis performed in wild spat within a biomonitoring network highlighted a DNA aneuploidy rate as high as 20\% (Benabdelmouna et al., 2011). Inputs of pollutants such as pesticides have already been detected in the Marennes Oleron basin in Spring due to rainfall events during the highly sensitive period of oyster gametogenesis (Munaron et al., 2003; Munaron, 2004; Burgeot et al., 2008). This latter observation suggest that the DNA hypodiploidy detected in production areas may be linked to genotoxic pollutant discharges in water. As oysters have been shown to be particularly vulnerable to physiological and environmental stressors during the reproduction period, pollutants could have a direct genotoxic effect on the genitors themselves, together with an indirect genotoxic effect on offspring due to the exposure of parental germ cells. 
Genotoxicity is common to several families of major environmental pollutants. Pollutant genotoxicity has been well-investigated in marine invertebrates and in particular in oysters and mussels (Bouilly et al., 2003; Wessel et al., 2007; Marcheselli et al., 2011; Akcha et al., 2012; Dallas et al., 2013). Exposing organisms to genotoxicants can result in reversible and irreversible DNA lesions. Primary DNA lesions, such as single or double-strand breaks, DNA base modifications and DNA adducts can be rapidly overcome by the cellular DNA repair machinery (Mateuca et al., 2006). Conversely, irreversible chromosomal damage may result in perturbations of cell division leading to chromosomal aberrations and variations of nuclear DNA content. In addition to somatic cells, gametes have been shown to be particularly sensitive to genotoxicant exposure (Speit et al., 2009; Favret and Lynn, 2010; Akcha et al., 2012; Lewis and Ford 2012). Despite nuclear DNA damage, male gametes can nevertheless contribute to the following generation (Lewis et Galloway, 2009; Devaux et al., 2011). The parental transmission of pollutant-induced DNA damage further to exposure to herbicides and cadmium has already been demonstrated in oysters in terms of aneuploidy (Bouilly et al., 2004, 2007). Moreover, various phenotypic consequences have been associated with the transmission of DNA damage in terms of developmental abnormalities (Lewis and Galloway, 2009; Devaux et al., 2011; Lacaze et al., 2011; Santos et al., 2013). In oysters, aneuploidy has been shown to be negatively correlated with growth rate and survival rates during summer mortality in adults by karyotyping (Leitao et al., 2001; Wilson et al., 2002), and spat by flow cytometry (Benabdelmouna et al., 2011), respectively.

In this study, oyster genitors were exposed to diuron during gametogenesis with the aim of studying the parental transmission of herbicide-induced DNA damage and its potential consequences on oyster physiological fitness. Diuron is the most widely-found biocide in antifouling paints and one of the WFD's priority pollutants. Although it has been banned in France since 2008 (JO n 204 September 4, 2007), diuron is still found in high concentrations in coastal waters (Munaron et al., 2012; Caquet et al., 2013). Moreover, diuron has already been reported as having diverse toxic effects on oysters, including somatic and gamete cell genotoxicity (Bouilly et al., 2007; Wessel et al., 2007; Akcha et al., 2012; Mai et al., 2013), embryotoxicity (Akcha et al., 2012; Mai et al., 2013), and immunotoxicity (Gagnaire et al., 2006, 2007; Luna-Acosta et al., 2012).

For this purpose, the extent of genomic abnormalities was analyzed in genitors, their gametes, larvae and spat for the detection of somatic and/or heritable genetic effects using two complementary approaches. The Comet assay was applied to detect early reversible primary DNA damage, while flow cytometry (FCM) was used to measure the prevalence of abnormal 
133

134

135

136

137

138

139

140

141

142

143

144

145

146

147

148

149

150

151

152

153

154

155

156

157

158

159

160

161

162

163

164

genomic profiles (variability in $\mathrm{CV}$ and genome size). In marine invertebrates, flow cytometry has been widely used to highlight genomic abnormalities (DNA breakage and DNA ploidy) (Barsiene et al., 2006; Goanvec et al., 2008; Jung et al., 2011; Theodorakis et al., 2012) and is recognised as a high precision technique (Bihari et al., 2003). Moreover, it has an advantage over other cytological assays because a larger number of cells can be analysed rather than in chromosome or micronucleus assay (Deaven, 1982; Bickham, 1990), allowing a rapid analysis of a large number of samples.

The presence of DNA damage in the spermatozoa of diuron-exposed genitors was also assessed in order to investigate the potential links between damaged DNA transmission and embryo-larvae development and growth, up to spat stage.

\section{Materials and methods}

\subsection{Chemical reagents}

Diuron (Pestanal, analytical standard), acetonitrile (anhydrous, 99.8\%), NaCl, Trizma base, DAPI, Dimethyl sulfoxide (DMSO), normal and low melting point agarose, Triton X-100, fetal calf serum, and GelRead were purchased from Sigma Aldrich Chemicals (France). $\mathrm{MgCl}_{2}-6 \mathrm{H}_{2} \mathrm{O}$ was purchased from Euromedex. DNA reference calibrator (Trout Red Blood Cells, TRBC) was purchased from Beckman Coulter (France).

Pesticides analytical standards including deuterared pesticides used as internal standards were obtained from Cluzeau Info Labo (Ste-Foy-la-Grande, France; purity >96\%). Dichloromethane and methanol (HPLC reagent grade, Scharlau) were obtained from ICS (Belin-Beliet, France). Ultrapure deionised water was prepared using a Milli-Q system (Millipore, Molsheim, France).

All POCIS (Polar organic chemical integrative samplers) used were pharmaceutical POCIS with PRC (Performance Reference Compounds). Each POCIS contained $200 \mathrm{mg}$ of Oasis® HLB bulk sorbent $(60 \mu \mathrm{m})$ (Waters, Guyancourt, France) enclosed between two hydrophilic polyether sulfone (PES) membrane disc Filters $(0.1 \mu \mathrm{m}, 90 \mathrm{~mm}$ membrane diameter) (VWR, Fontenay-sous-Bois, France) and held together with stainless steel rings (hole diameters $=54$ $\mathrm{mm}$ ). Selected performance reference compounds (d5-DIA) were added into the sorbent of POCIS prior to exposure at a concentration of $10 \mu \mathrm{g} \mathrm{g}^{-1}$ (Mazzella et al., 2010). 


\subsection{Genitor origin and oyster husbandry}

166 The adult Pacific oysters (Crassostrea gigas) used for this experiment originated from wild genitors collected in the Marennes-Oléron Bay (France). They were used in the framework of a selection program aimed at producing oyster families with an improved resistance to summer mortality. These oysters showed an average survival rate during mortality periods.

170 For our experiment, they were transferred from the field to the hatchery for a one-month acclimatization period. Seawater was pumped directly from the Seudre river Estuary, filtered

172 through a sand filter $(40 \mu \mathrm{m})$ and passed through UV rays before draining the tanks in a 173 continuous flow system (output : $55 \mathrm{~L} \mathrm{~h}^{-1}$ ). Good seawater oxygenation was hence provided by 174 circulation, coupled with an additional bubbling system. Oyster feeding was controlled: 175 oysters were fed daily with a mixture of four marine microalgae (Skeletonema costatum: $1760.6 \times 10^{6}$ cellules $\mathrm{mL}^{-1}$, Isochrysis galbana: $4 \times 10^{6}$ cellules $\mathrm{mL}^{-1}$, Tetraselmis suecica: $0.8 \times 10^{6}$ 177 cellules $\mathrm{mL}^{-1}$, Chaetoceros gracialis: $4 \times 10^{6}$ cellules $\mathrm{mL}^{-1}$ ). Water temperature was 178 maintained at $8^{\circ} \mathrm{C}\left( \pm 1^{\circ} \mathrm{C}\right)$ throughout the acclimatization period. In order to initiate the oyster 179 gonad maturation process, the temperature was then raised by two degrees per day for 1 week, to reach $19.8^{\circ} \mathrm{C}\left( \pm 0.3^{\circ} \mathrm{C}\right)$ at the start of the experiment.

\subsection{Diuron exposure during oyster gametogenesis}

183 Once gonad development had begun, the oysters were divided into three experimental groups: a seawater control, a solvent control and a diuron-exposed group. As diuron was prepared in acetonitrile, the solvent control group was exposed to acetonitrile at a concentration of $0.005 \%$.

Three 250-L tanks were used for each experimental group, each receiving 240 oysters. Two 7day exposure periods took place at the start and mid-course of gametogenesis by exposing oysters to 0.4 and $0.6 \mu \mathrm{g} \mathrm{L}^{-1}$ of diuron respectively. These short exposure pulses were chosen to mimic rain events with concentrations of diuron close to those detected in coastal waters (Table 1).

192 The oysters were maintained in a closed circulation system throughout the exposure period.

193 The seawater was changed every morning and diuron and acetonitrile were added every day after seawater renewal to reach target concentrations in the tanks. The temperature was kept stable at $20^{\circ} \mathrm{C}$ and feeding was controlled as described previously. Mortality was assessed for the all duration of the experiment in each experimental tank.

197 It is noteworthy that mortality was very high in some tanks (up to $40 \%$ in control tanks) by the end of the first pulse of herbicide exposure. All moribund oysters displayed high bacterial 
199

200

201

202

203

204

205

206

207

208

209

210

211

212

213

214

215

216

217

218

219

220

221

222

223

224

225

226

227

228

229

230

231

232

loads with, in particular, the presence of Vibrio aestuarianus: a pathogenic bacteria with high virulence for Crassostrea gigas. Some strains can induce a mortality rate of about $90 \%$ in oysters at seven days post-injection (Labreuche, 2006). In order to cope with this bacterial infection and avoid the total loss of the biological material, all oyster batches were subjected to a 5-day antibiotic treatment (10 $\mathrm{mg} \mathrm{L}^{-1}$ of Flumequine). At the end of the treatment, the oysters were then allowed to recover for 11 days prior to the second herbicide pulse.

At the end of the second herbicide pulse, oysters from each group were then grown in normal conditions for an additional period of three weeks in order to reach maturity and allow production of the next generation (Fig. 1).

\subsection{Gamete handling, fertilization, and larval and spat culture}

At the end of oyster gametogenesis, crosses were performed using genitors from the same experimental group ( $n=70$ oysters per group). Spawning was induced in males and females by thermal shock (from $18^{\circ} \mathrm{C}$ to $28^{\circ} \mathrm{C}$ for $30 \mathrm{~min}$.). The number of spawning males and females was 24 and 45, 11 and 36, 20 and 32 for the seawater control, solvent control and diuronexposed groups respectively. Gametes from each individual were filtered on a $45 \mu \mathrm{m}$ sieve for males and a $75 \mu \mathrm{m}$ sieve for females, then suspended in $1 \mu \mathrm{m}$ filtered sea water (FSW) at $25^{\circ} \mathrm{C}$. Oocytes and spermatozoa from each individual male and female were then pooled. For each experimental group, 9000000 oocytes were used and fertilization was achieved with a ratio of 200 spermatozoa per oocyte.

One hour post-fertilization, the embryos were divided into three replicates $(n=3000000$ embryos per tanks) and transferred to 30-L glass fiber tanks filled with $1 \mu \mathrm{m}$ FSW at 22$24^{\circ} \mathrm{C}$. They were grown for $24 \mathrm{~h}$ up to D-larvae at a density of 100 larvae $\mathrm{mL}^{-1}$. The tank water was changed every two days from this development stage onwards; the larvae were reared until metamorphosis was achieved at a temperature of $24-25^{\circ} \mathrm{C}$ and fed with a mixture of algae (Isochrysis galbana, Chaetoceros gracilis, Skeletonema costatum). Larvae density was assessed by means of microscope counts for each batch to further limit competition: larval concentration was progressively reduced from 10 to 5 and 3 larvae $\mathrm{mL}^{-1}$ on day 1,5 and 7 post-fertilization respectively. At the eyed larvae (pediveliger) stage, the larvae were ready to settle; they were then transferred to the micronursery into $150 \mu \mathrm{m}$ sieve-bottomed trays in a FSW downweller system at $20^{\circ} \mathrm{C}$, using oyster shell cultch as a settlement medium. The sea water was enriched every day with a mixture of four algal species routinely produced at the hatchery (Isochrisis galbana, Chaetoceros gracilis, Tetraselmis suecica, and Skeletonema costatum). The sieves were washed daily and changed regularly depending on spat growth. 


\subsection{Sampling program}

234

235

236

237

238

239

240

241

242

243

244

245

246

247

248

249

250

251

252

253

254

255

256

257

258

259

260

261

262

263

264

265

266

Sampling was performed at various stages of the oyster life cycle during the course of the experiment. The genitors exposed during gametogenesis were sampled at the beginning and end of the two herbicide pulses and at spawning time, when gametes from each genitor groups (controls and diuron-exposed) were also analysed. In order to study putative vertical effects on the next generation, larvae and spat originating from each genitor group were also sampled as described in Figure 1. The number of individuals and type of tissue/fluid sampled for each type of chemical and biological analysis are shown in Table 2.

\section{Samplers \\ 2.6 Chemical analysis of seawater using Polar Organic Chemical Integrative} Polar organic chemical integrative samplers (POCIS) are used for the detection of hydrophilic pollutants $\left(1<\log \mathrm{K}_{\mathrm{ow}}<4\right)$ such as pesticides, pharmaceutical substances, detergents and hormones. POCIS allow sampling of the dissolved water fraction that is thought to be bioavailable for living organisms over period of several weeks, allowing the determination of the Time Weighted Average (TWA) concentration of a substance. In our study, they were used in two aims, (1) to assess the chemical quality of seawater used at the hatchery and, (2) to obtain an integrated measurement of the concentration of diuron reached during the pulses. For this purpose, one out of the three tanks used for the seawater control and diuron-exposed tanks were equipped with a deployment cage. Two sampling strategies were adopted. POCIS were used in duplicate during the all experiment duration, with some replacements to avoid fouling onto the membranes. They were also used during the 7 day-exposure pulses to measure the TWA of diuron reached in the exposed tanks during the pulse.

POCIS were used for the detection of diuron and its main metabolites (1- $(3,4$ dichlorophenyl)-urea known as dcpu; 1-(3,4dichlorophenyl)-3 methyl-urea known as dcpmu) and of 54 other pesticides: 1-(2,4dichlorophenyl)-urea, acetochlor, acetochlor ESA (ethane sulfonic acid), acetochlor OA (oxanilic acid), alachlor, amethryne, atrazine, atrazine 2 hydroxy, azoxystrobine, bentazone, carbendazime, carbetamide, carbofuran, carbosulfan, chlorotoluron, chlorsulfuron, cyanazine, cyromazine, desethyl atrazine (DEA), desisopropyl atrazine (DIA), diflufenican, dimetachlor, dimethylaminosulfanilide (DMSA), N,N-dimethylN'-p-tolylsulfamide (DMST), flazasulfuron, fluazifop-p-butyl, flusilazole, hexazinone, hydroxysimazine, imidaclopride, irgarol, isoproturon, linuron, metazachlore, methiocarb, metolachlore, metolachlore ESA (ethane sulfonic acid), metolachlor OA (oxanilic acid), 
metoxuron, metsulfuron-methyl, nicosulfuron, promethrine, propachlore, propazine, propiconazole, prosulfuron, pymethrozine, quizalofop-ethyl, quizalofop-p-tefuryl, simazine, terbutrine, terbutylazine, terbutylazine desethyl, thiamethoxan.

POCIS extraction and analysis were performed as described by Tapie et al. (2011). Briefly, the sorbent from each POCIS was transferred into an empty glass solid phase extraction (SPE) tube by rinsing it with ultra-pure water, then vacuum-dried for $1 \mathrm{~h}$. Internal standards (d13alachlor, d5-atrazine, d3-carbofuran, d6-diuron, d6-hexazinone, d9-irgarol, d10-simazine, d5terbutylazine) were gravimetrically added and the sorbent was eluted successively using 10 $\mathrm{mL}$ of methanol, $10 \mathrm{~mL}$ of a methanol/dichloromethane mixture (v/v: 50/50), and finally 10 $\mathrm{mL}$ of dichloromethane. The extract was concentrated first by using a vaccum evaporation system, dried under a stream of nitrogen and then dissolved in $150 \mathrm{~mL}$ of methanol for pesticides analysis by LC/MS/MS. The quantification of the gross mass of each chemical sequestered is expressed below as the concentration per POCIS in $\mathrm{ng} \mathrm{g}^{-1}$ of sorbent. From these data, TWA concentrations $\left(\mathrm{Cw}, \mathrm{ng} \mathrm{L}^{-1}\right)$ can be derived, corresponding to the average concentration of a contaminant present in the water sampled during the exposure period of the sampler. These TWA concentrations are derived from the concentration of contaminant sequestered in POCIS ( $\mathrm{Cp}, \mathrm{ng} \mathrm{g}^{-1}$ ), from the exposure time ( $\mathrm{t}$, days) and from the sampling rate (Rs, $\mathrm{L} \mathrm{day}^{-1} \mathrm{~g}^{-1}$ ) of each contaminant assessed during a laboratory calibration and are bound by the following equation (Alvarez et al., 2004; Vrana et al., 2005):

$$
\mathrm{Cw}=\mathrm{Cp} \cdot \mathrm{Rs}^{-1} \cdot \mathrm{t}^{-1}
$$

\subsection{Time-course of genitor growth}

Genitor growth was monitored in each assay group throughout the experiment by measuring shell length and wet weight at each of the sampling points.

\subsection{Measurement of primary structural DNA damage by the Comet assay}

Analysis of genitor and spat hemocytes. The hemolymph of each individual was collected by punction from the posterior adductor muscle sinus using a sterile hypodermic needle $(23 \mathrm{G})$ in a $2 \mathrm{~mL}$ syringe pre-rinsed with the anticoagulant Alsever's solution (113.7 mM glucose, 27.2 $\mathrm{mM}$ sodium citrate, $58.44 \mathrm{mM}$ sodium chloride, $\mathrm{pH}$ 6.1). A volume of Alsever's solution (0.1 $\mathrm{mL}$ ) remained in the syringe to achieve a 1:5 dilution of the withdrawn hemolymph. The hemocytes were recovered by centrifugation $(1500 \mathrm{rpm}, 5 \mathrm{~min})$ and the hemocyte pellet was resuspended in $1 \mathrm{~mL}$ of freezing medium (55\% RPMI 1640 medium, $25 \%$ fetal calf serum, 
$20 \%$ DMSO) and stored in liquid nitrogen prior to analysis. Suspension in freezing medium and storage in liquid nitrogen was already performed and validated in hemolymph and gill cells of the blue mussel (Akcha et al., 2004). The samples were slowly defrosted at room temperature prior to the Comet analysis. Two slides were prepared for each sample and the Comet assay was conducted as previously described (Akcha et al., 2003; Wessel et al., 2007). DNA migration was performed for $15 \mathrm{~min}$ at $23 \mathrm{~V}\left(390 \mathrm{~mA}, E=0.66 \mathrm{Vcm}^{-1}\right)$. At the end of electrophoresis, the slides were washed by incubation for $3 \times 5$ min in Tris base $0.4 \mathrm{M}, \mathrm{pH} 7.5$. In order to obtain permanent preparations, the slides were immersed in absolute ethanol for 10 min to dehydrate, then dried at room temperature. Just prior to analysis, $75 \mu \mathrm{L}$ of GelRed at 8 $\mathrm{mg} \mathrm{L}^{-1}$ were spread over each slide using a cover glass. The slides were placed for at least $1 \mathrm{~h}$ in the dark at $4^{\circ} \mathrm{C}$ for coloration, then analysed using an optical fluorescence microscope (Olympus BX60, ×40) equipped with a CDD camera (Luca-S, Andor Technology) and image analysis system (Komet 6, Kinetic Imaging Ltd.). At least 50 nuclei were analysed per slide and the percentage of DNA present in the Comet tail (\% Tail DNA) was measured for each observed nucleus.

Analysis of genitor spermatozoa. The semence from 18 males (6 per tank) was analysed individually in each assay group. At the outset of gamete emission, each identified male was isolated in a beaker containing $250 \mathrm{~mL}$ of FSW. Dilution in CMFS (137 mM NaCl, $2.7 \mathrm{mM}$

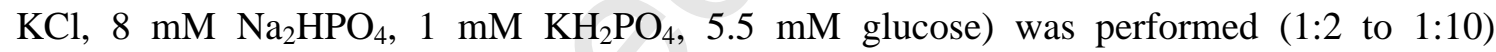
depending on the concentration of the sperm sample. The Comet assay was performed on fresh samples, as described previously in this paper for genitor hemocytes. Following agarose embedding, a prior digestion step by proteinase $\mathrm{K}$ was not added to the protocol to decondense the DNA as already performed in human sperm by other authors (Morris et al., 2001). As a matter of fact, the Comet assay was previously validated without a decondensation step in oyster sperm following exposure to the model direct genotoxicant, hydrogen peroxide (Akcha et al., 2012). In fish such the three-spined stickleback, the Comet assay was also applied with success to assess sperm DNA damage without proteinase $\mathrm{K}$ digestion (Santos et al., 2013).

\subsection{FCM analyses of nuclear DNA damage}

FCM analyses were performed individually on genitors and spat. Regarding genitors, the same individuals (identified by marking) were monitored throughout the experiment by anesthesia, whereas spat sampling was destructive. In both cases, nuclei were extracted from small pieces $\left(1 \mathrm{~mm}^{2}\right)$ of gills, mixed with $2 \mu$ trout red blood cells (TRBC, Coulter DNA 
Reference Calibrator, 629972) as internal standard solution, then stained with DAPI at a concentration of $2 \mu \mathrm{g} \mathrm{mL}^{-1}$ in $2 \mathrm{~mL}$ final volume. At least 2,000 nuclei were analyzed for each sample. FCM was performed on a PARTEC CyFlow ML with the following features: excitation-365 nm UV LED, UG $1(290-410 \mathrm{~nm}, 3 \mathrm{~mm})$, chromatic beam splitter (TK 420), emission-beam splitter (TK 420, TK 560) and barrier filter (CG 455) for DAPI signals. Peak positions and coefficients of variation (CVs) were calculated automatically (PARTEC PAS II software package). In this study, FCM analyses of genome size variation meant that changes in the number or composition of individual chromosomes were not measured directly by karyological analyses. Therefore, as suggested by Suda et al. (2006), classical cytogenetic terminology was preceded by the prefix "DNA" (DNA-ploidy level, DNAhypo/hyperdiploidy, DNA-polyploidy, etc.). The DNA index is used to estimate DNA ploidy level variations (DNA aneuploidy and polyploidy) by measuring mean nuclear DNA content (genome size). $\mathrm{CV}$ is used to measure intra-individual genome size variability, in order to assess clastogenic effects (presence of different cell populations with different amounts of DNA breaks within an individual). High CVs have previously been shown to be associated with cell populations with varying DNA contents, most commonly resulting from chromosomal aberrations caused by experimental or environmental exposure to clastogenic agents (Lamb et al. 1995; Lowcock et al. 1997; Bickham et al. 1998).

For the purpose of our study, only samples with internal standard cells showing a CV below $3 \%$ were considered for subsequent analyses. The ratio between the respective positions of sample and TRBC G0/G1 peaks is characteristic of sample DNA ploidy level. In our laboratory conditions, this DNA index was equal to 0.42 (+/-5\%) for diploids. Values below this ratio indicate a decrease in genome size (DNA hypodiploidy), whereas values above this ratio indicate an increase in genome size (DNA hyperdiploidy).

\subsection{The effects of parental exposure on offspring development and growth}

Hatching rate refers to the percentage of embryos reaching the D-larvae stage twenty-four hours after fertilization, according to the initial number of oocytes used for fertilization. All larvae were collected from each tank by sieving on a $45 \mu \mathrm{m}$ nylon mesh, then placed in a graduated beaker. After homogenization, the larvae were counted using a binocular microscope (Olympus BX41, x100). At this stage, all larvae that were not D-shaped were considered as abnormal. Larvae samples were placed at a concentration of 50,000 individuals per liter of FSW and fixed using $50 \mu \mathrm{l}$ of $8 \%$ neutralized formalin solution. The percentage of abnormal D-shell larvae was scored out of 3x100 individuals in each tank. Abnormalities (D- 
368

369

370

371

372

373

374

375

376

377

378

379

380

381

382

383

384

385

386

387

388

389

390

391

392

393

394

395

396

397

398

399

400

larvae presenting mantle and/or shell abnormalities) were determined according to the criteria given by His et al. (1999) and Quiniou et al. (2005). To further characterize developmental abnormalities, fertilized oocytes from each assay group were saved in beakers at a concentration of 50,000 per liter prior to transfer to 30-L glass fiber tanks, in order to perform a standardized embryo-larval bioassay in accordance with French standards (AFNOR XPT90-382, September 2009).

Larvae growth was then monitored in relation to different size classes (45-60-70-85-100-125150-180-220 $\mu \mathrm{m})$ up to the spat stage.

\subsection{Statistical analysis}

Statistical tests were conducted using STATISTICA (StatSoft, Inc. (2011), version 10). Normality was checked using Lilliefor's test and variance homogeneity was evaluated using Bartlett's test. In order to achieve normality, raw data from the Comet assay were mathematically transformed ( $\mathrm{Ln} \mathrm{x}$ ) before proceeding with an ANOVA, taking into account both the experimental group and sampling time as factors. ANOVA was also used to handle developmental abnormality data. When significant, a posteriori Tukey test was performed. Data on growth, hatching rate and flow cytometry could not be normalized, statistical differences between treatments were tested using the non-parametric Kruskal-wallis test.

\section{Results}

\subsection{Seawater contamination}

Background pesticide contamination of the seawater used at the hatchery. The analysis of the POCIS from the control tank provided information on the background level of pesticide contamination of the seawater used at the experimental hatchery. The results obtained are summarized in Table 3 . They showed that out of the 57 pesticides analyzed, $36 \%$ were detected. Among the latter substances, metolachlor derivatives (metolachlor ESA and metolachlor OA) and DEA (desethyl atrazine) are those presenting the highest concentrations (close to 30 and $60 \mathrm{ng} \mathrm{L}^{-1}$ respectively). Of note, variations in the measured concentrations were observed between the two POCIS immersion periods for some of the detected substances. That was the case for DEA, which was detected at a concentration of $57 \mathrm{ng} \mathrm{L}^{-1}$ during the first 29 days of the experiment, but was present at $4 \mathrm{ng} \mathrm{L}^{-1}$ only during the second consecutive immersion period. During the experiment, the total pesticide concentration in the water from the hatchery was 0.15 and $0.08 \mu \mathrm{g} \mathrm{L}^{-1}$ for the two POCIS immersion periods. 
401 Diuron was detected at a mean concentration of 77 and $62 \mathrm{ng} \mathrm{L}^{-1}$ that is nearly one order of 402 magnitude lower than the concentrations tested in our study. None of its metabolites were 403 detected.

404 Assessment of reached diuron concentration in assay tanks. Using the passive samplers, the 405 diuron concentrations targeted during the experiment were shown to be around $20 \%$ and $49 \%$ 406 lower than expected, respectively without and with PRC correction, e.g. oysters were exposed 407 to $0.30 \mu \mathrm{g} \mathrm{L}^{-1}$ of diuron rather than $0.6 \mu \mathrm{g} \mathrm{L}^{-1}$ for the second herbicide pulse taking into account the data obtained after PRC correction (Table 4).

409

410

411

412

413

414

415

416

417

418

419

420

421

422

423

424

425

426

427

428

429

430

431

432

433

\subsection{Effects of diuron exposure on genitors}

\subsubsection{Growth}

At the end of the first herbicide pulse, the genitors exposed to diuron showed a significantly lower wet weight than those from the control groups, with values of $3.08 \pm 1.01 \mathrm{~g}$ for diuronexposed genitors versus $3.87 \pm 1.27 \mathrm{~g}$ and $3.89 \pm 1.10 \mathrm{~g}$ for genitors from the seawater and solvent control groups $(\mathrm{p}<0.009)\left(7\right.$ days at $\left.0.4 \mu \mathrm{g} \mathrm{L}^{-1}\right)$. This lower wet weight was also observed at the end of the second herbicide pulse, with values of $3.35 \pm 1.03 \mathrm{~g}$ for diuronexposed genitors versus $3.98 \pm 1.21 \mathrm{~g}(-16 \%)$ and $4.16 \pm 1.28 \mathrm{~g}(-19 \%)$ for those from the seawater and solvent controls $(\mathrm{p}<0.02)$ (Fig. 2). No differences were observed in genitor growth in terms of shell length and width across the experimental groups $(\mathrm{p}>0.05)$.

\subsubsection{DNA damage in hemocytes and gill cells}

The results of the Comet assay revealed a significant increase in DNA strand breaks in the hemocytes of genitors exposed to diuron at the end of the first herbicide pulse $(p<0.001)$. This increase was even higher at the end of the second pulse, reaching a mean percentage of $33 \%$ DNA in Comet tails, versus less than $20 \%$ in the controls $(\mathrm{p}<0.001)$. The amount of DNA strand breaks remained stable in the control groups, except at the end of the second herbicide pulse in the solvent control groups, when a slight increase was recorded (p=0.01) (Fig. 3).

Although primary DNA lesions were induced in diuron-exposed genitors, analysis of the data obtained by FCM showed no significant variations in the extent of chromosome breakage (CVs) and genome size in the gills of the same individuals. (Table 5). 
3.2.3 DNA damage in male gametes

435

436

437

438

439

440

441

442

443

444

445

446

447

448

449

450

451

452

453

454

455

456

457

458

459

460

461

462

463

464

465

466

467

Male gamete analysis using the Comet assay showed a significantly higher level of DNA strand breakage in the spermatozoa of genitors exposed to diuron versus the controls $(\mathrm{p}=0.001)$ (Fig. 4). Despite a marked increase in DNA damage, the percentage of breaks in the Comet tail of spermatozoa nucleus remained below $10 \%$.

\subsection{Effect of parental diuron exposure on offspring}

\subsubsection{Hatching rate, embryo-larvae development and growth}

Although no differences were found in fertilization success across the three groups, a significantly lower hatching rate was observed for offspring from genitors exposed to diuron: $42.4 \pm 5.9 \%$ vs $79.3 \pm 10.8 \%$ and $76.7 \pm 12.1 \%$ for the seawater control and solvent control groups respectively $(\mathrm{p}<0.005)$ (Fig. 5). Moreover, a higher level of D-larvae abnormalities was observed in offspring from diuron-exposed genitors $(\mathrm{p}<0.05)$. Of note, the offspring of genitors exposed to acetonitrile also showed significant developmental abnormalities ( $\mathrm{p}<0.01)$. The mean percentage of larval abnormalities was $20.8 \pm 9.5 \%, 38.9 \pm 5.6 \%$ and $30.2 \pm 5.2 \%$ respectively in offspring from seawater control, solvent control and diuronexposed genitors (Fig. 5).

On the other hand, embryo-larval bioassay results revealed a significantly higher level of embryo-larvae abnormalities only in larvae originating from diuron-exposed genitors $(18 \pm 3$ $\%$ versus $7 \pm 3$ and $6 \pm 2$ for larvae from the seawater and solvent controls).

A slower growth rate was only observed in larvae from genitors exposed to diuron. In the control groups, ready-to-settle pediveliger larvae were obtained after 20 days of rearing, whereas 24 days were required to reach the same stage for larvae from diuron-exposed genitors (Fig. 5).

\subsubsection{DNA integrity of offspring}

The DNA integrity of spat from the various experimental groups was analysed using the Comet assay to check for the parental transmission of diuron-induced DNA damage. No difference in the level of DNA strand breaks in spat hemocytes was observed across the various batches originating from the two control groups and diuron-exposed genitors $(p=0.23)$ (Fig.6).

Conversely, FCM analysis showed both clastogenic and aneugenic effects in the gills of spat from diuron-exposed genitors: the nuclei isolated from gill tissue had significantly higher CVs 
468 versus the controls, indicating more extensive clastogenic effects $\left(\mathrm{p}<10^{-6}\right)$. The mean 469 coefficient of variation was $5.72 \pm 1.11$ in spat from diuron-exposed genitors vs $4.58 \pm 0.49$ 470 and $4.54 \pm 0.49$ in spat from the seawater and solvent controls respectively. Additionally, $47130 \%$ of individual spat originating from diuron-exposed genitors showed high CVs (at least 472 twice the value obtained for the internal standard TRBC), with values ranging from 6 to 11.5 $473 \%$. In contrast, only $2 \%$ of spat from the control groups showed such high CVs, with a 474 maximum value of $7.08 \%$ (Fig.7).

475 Moreover, a significant decrease $\left(\mathrm{p}<10^{-6}\right)$ in nuclear DNA content was also measured in spat 476 from diuron-exposed genitors $(0.413 \pm 0.020)$, with over $15 \%$ of individuals showing DNA 477 hypodiploidy with a DNA index lower than the euploid DNA index of 0.400 . Hypodiploid 478 individuals accounted for just $2 \%$ in the control groups $(0.427 \pm 0.009$ and $0.423 \pm 0.008$ 479 respectively for the seawater and solvent control groups). The lowest DNA index values were 480 481 $0.39,0.38$ and 0.34 for offspring from seawater control, solvent control and diuron-exposed genitors respectively (Fig. 7)

482

483

\section{Discussion}

\subsection{Seawater contamination}

Background pesticide contamination of the seawater used at the hatchery. POCIS are generally used to assess the contamination of water systems by hydrophilic substances. In this paper, their results initially provided information on the background level of contamination of the seawater used at the hatchery. In fact, UV treatment and filtration are not expected to eliminate the pollutants drained by Seudre River. The background contamination of the water used at the hatchery appeared low considering the few data available on the detection of pesticides in coastal water by the use of POCIS (Munaron et al., 2012, Alvarez et al., 2013). In the study from Munaron et al. (2012), POCIS were used to assess pollution by pharmaceuticals, alkylphenols, herbicides and biocides in the French Mediterranean coast. Among the herbicides analysed, diuron was the only one detected in all the samples and at concentrations as high as $30 \mathrm{ng} \mathrm{L}^{-1}$, the other detected herbicides (terbuthylazine, atrazine, irgarol, simazine) being at concentrations lower than $2.5 \mathrm{ng} \mathrm{L}^{-1}$.

497 In the present study, the use of POCIS also allowed us to show variations in water 498 concentrations of some of the detected herbicides that are thought to result from irregular discharges of these molecules into the water, due to both agricultural practices and weather 
501

502

503

504

505

506

507

508

509

510

511

512

513

514

515

516

517

518

519

520

521

522

523

524

525

526

527

528

529

530

531

532

533

concentrations. Metolachlor is a member of the chloroacetanilide herbicide family, widely used for maize and sorgho treatment. It was banned in France in 2003, but its active isomere S-metolachlore is still authorized. ESA and OA metolachlor metabolites could originate from metolachlor itself or from S-metolachlore degradation. DEA is a residue of atrazine, which was banned in France in 2001. However, atrazine has a high remanence and is still regularly detected in its parent and residue forms in surface and coastal waters.

Assessment of reached diuron concentration in assay tanks. Diuron concentrations in the assay tanks at the end of the herbicide pulses were determined using POCIS and a diuron loss of up to $49 \%$ was observed. As previously demonstrated by Luna-Acosta et al. (2012), a 19\% diuron loss due to volatilization or adsorption on tank walls and oyster shells can be achieved by exposing oysters to $1 \mu \mathrm{g} \mathrm{L}^{-1}$ of diuron for 24 hours. Diuron is fairly persistent in seawater and is not expected to degrade, as highlighted by the absence of diuron metabolites in water. Thomas et al. (2002) reported no degradation of diuron in seawater at $15^{\circ} \mathrm{C}$ over a 42 dayperiod.

In our study, oysters were exposed to even lower concentrations than expected. Our initial target concentrations were medium environmental concentrations (Table 1), hence highlighting the relevance of the effects observed on oyster DNA. Due to the general pollution of the water systems, the presence of pollutants at trace levels in the water used at the hatchery was shown by the use of POCIS. As a consequence, it can't be excluded the possibility of background pollutants contributing to the toxic effects reported in the present study. However, differences with seawater control groups were sufficiently obvious to allocate most of the toxic effects observed in oysters to diuron.

\subsection{Genotoxicity assessment in genitors}

Oysters used for our experiment were wild genitors and so naturally exposed to microorganisms present in the environment. There is nowadays no possibility to use germ free oysters. Some of these microorganisms are pathogenic for the oysters such as the bacteria Vibrio aestuarianus, those pathogenicity was revealed when increasing the temperature to initiate gonad maturation. It is noteworthy that the flumequine treatment performed between the two herbicide pulses to eradicate the bacterial infection could have led to the production of ROS-induced DNA damage as previously observed in other organisms (Kashida et al., 2002).

However, flumequine is known to be rapidly eliminated as demonstrated in the sea bass (Rigos et al., 2002). Moreover, the oxidative damage induced by this molecule in terms of 
534 DNA strand breaks have been shown to be rapidly formed and repaired in rodent (Kashida et 535 al., 2002). The 11 day between the end of the flumequine treatment and the beginning of the 536 second herbicide pulse is so expected to be sufficient to turn back to basal DNA damage 537 level. The absence of variation in the level of DNA strand breaks in the control groups 538 following flumequine treatment seemed to confirm this point.

539 In our study, the Comet assay revealed significant increases in DNA strand breaks in genitor 540 hemocytes further to diuron exposure. Similar genotoxic effects of diuron have already been 541 demonstrated using the Comet assay in adult European topminnow (Phoxinus 542 phoxinus) exposed to chronic environmental concentrations of diuron $\left(1-2 \mu \mathrm{g} \mathrm{L}^{-1}\right)$ and 543 axoxystrobin $\left(0.5-1 \mu \mathrm{g} \mathrm{L}^{-1}\right.$ ) (Bony et al., 2008). DNA strand breaks in diuron-exposed 544 organisms could be associated with oxidative stress induction. Indeed, Bouilly et al. (2007) 545 highlighted an increase in reactive oxygen species (ROS) production in oyster hemocytes 546 following a 4-week exposure to 0.3 and $3.0 \mu \mathrm{g} \mathrm{L}^{-1}$ of diuron. Moreover, diuron appears to 547 decrease also the activities of antioxidant defenses: a significant decrease in the activity of the 548 antioxidant enzyme superoxide dismutase was already observed in the oysters further to 6 and $54924 \mathrm{~h}$ exposure to $1 \mu \mathrm{g} \mathrm{L} \mathrm{L}^{-1}$ of diuron (Luna-Acosta et al., 2012). The oxyradicals produced by 550 diuron-exposure in oysters could hence act as chemical nucleases for the DNA, resulting in 551 DNA strand breakage detectable by the Comet assay. The mechanisms involved in ROS 552 production haven't been identified yet for diuron but it may be linked with its 553 biotransformation. Oysters are seemigly capable of biotransforming diuron, as suggested by 554 the low bioconcentration factor (BCF) of diuron in oyster. The latter is reported to be as low 555 as 17 and 7 in the paper from Luna-Acosta et al. (2012) and Buisson et al. (2008) 556 respectively, highlighting the low ability of oyster to bioaccumulate diuron probably due to 557 metabolic activities.

558 Although diuron-induced primary DNA lesions were observed in genitor hemocytes, no 559 evidence of clastogenic or aneugenic effects was observed in gill cells using flow cytometry.

560 For a direct comparison, it would have been better to measure both genotoxicity biomarkers 561 in the same tissue cell types. As a matter a fact, DNA strand breaks were measured in 562 hemocytes by the Comet assay whereas clastogenic and aneugenic effects were analysed by 563 flux cytometry in gill cells. Cytometry analyses were also performed in hemocytes but the 564 results obtained were difficult to interprete due to the different cell populations present in 565 oyster hemolymph. On the other hand, the application of the Comet assay on gill cells 566 requiered a dissociation step that can be fastidious to operate when handling a lot of samples. 
567 In the present study, despite primary DNA damage was observed in hemocytes, no damage

568 was measured by flow cytometry in gill cells that are known to be particularly sensitive to 569 genotoxicant exposure (Akcha et al., 2000) and so target cells to assess DNA damage. This 570 difference in results can be explained by the fact that flow cytometry is dedicated to the 571 measurement of more severe DNA damage than the Comet assay. In fact, Bouilly et al. (2007) 572 showed diuron to significantly increase somatic aneuploidy (lowered chromosome number in 573 a percentage of somatic gill cells) when oysters were exposed to concentrations of $0.3 \mu \mathrm{g} \mathrm{L}^{-1}$ 574 and $3.0 \mu \mathrm{g} \mathrm{L}^{-1}$ but for a much longer exposure period of 11 weeks. Aneuploidy occurs when 575 replicated chromosomes (or chromatids) fail to segregate properly during cell division, 576 resulting in the production of cells with an abnormal number of chromosomes. Several 577 molecular mechanisms are involved in the induction of aneuploidy by chemicals during the 578 cell cycle, such as damage to the spindle apparatus (centrioles and kinetochores), effects on 579 chromosome (fragmentation, condensation or stickiness), induction of chromosome 580 interchanges, persistence of the nucleolus during mitosis or meiosis, alterations in ion 581 concentrations during mitosis (e.g. $\mathrm{Ca}+$ ) and damage to the nuclear membrane (Aardema et 582 al., 1998). Pesticide aneugenic activity has already been investigated, with the induction of 583 chromosome loss and non-disjunction observed in human lymphoblastoid cells further to 584 trichlorfon exposure (Doherty et al., 1996). Trichlorfon has been shown to interfere with the 585 mitotic spindle assembly by blocking cells in mitosis in vertebrates (Sun et al., 2000; Tian et 586 al., 2000; Cukurcam et al., 2004). Data from Mattiuzo et al. (2006) also showed that 587 dichlorvos can block cells in mitosis, possibly through interference with the mitotic spindle 588 assembly.

589 In parallel to primary DNA alterations, a significantly lower growth (wet weight) was 590 observed in genitors exposed to diuron versus the controls. Little data is available on the 591 effect of diuron on growth, and the diuron concentrations tested were very high and not 592 representative of those found in the natural environment. Effects on weight and growth have 593 already been observed in worms (Lumbriculus variegatus) and snails (Physa gyrina) 594 (Nebeker and Schuytema, 1998) when exposed to concentrations of 29.1 and $15.3 \mathrm{mg} \mathrm{L}^{-1}$ 595 respectively. Embryos from $P$. regilla and X. laevis had a higher rate of developmental 596 abnormalities and a reduced growth when exposed to diuron concentrations exceeding $20 \mathrm{mg}$ $597 \mathrm{~L}^{-1}$ (Schuytema and Nebeker, 1998). Regarding oysters, only one paper has previously 598 reported a negative impact of diuron on growth: a synergistic negative effect on growth (size) 599 was reported following 13 days of juvenile exposure to a herbicide (Basamaïs, $10 \mu \mathrm{g} \mathrm{L}^{-1}$ ) and 
600 fungicide (Opus, 10 $\mathrm{g} \mathrm{L}^{-1}$ ) (Stachowski-Haberkorn et al., 2008). As reported by Buisson et al. 601 (2008), diuron can have adverse effects on oysters at low concentrations in the case of short 602 exposure. In fact, after exposing oysters to a concentration of $1 \mu \mathrm{g} \mathrm{L}^{-1}$ for 1 week, a negative 603 effect was observed on both reproduction (partial spawning) and nutrition (atrophy of the 604 digestive epithelium).

605

606

\subsection{DNA damage in semence and effects on offspring}

607 Gamete cells (spermatozoa) are known to be sensitive to pollutant exposure (Speit et al., 608 2009; Favret and Lynn, 2010; Lewis and Ford, 2012) and specifically to diuron in C. gigas 609 (Akcha et al., 2012; Mai et al., 2013). By in vitro exposure, Akcha et al. (2012) showed 610 diuron to have significant genotoxic effects on oyster spermatozoa from concentrations of $6110.05 \mu \mathrm{g} \mathrm{L}^{-1}$ upwards. In our study, indirect genotoxic effects on oyster spermatozoa were 612 observed after exposing genitors during gametogenesis; it is hence probable that 613 spermatogonia DNA was damaged by diuron biotransformation. Despite the low level of 614 DNA strand breaks measured in spermatozoa, the induction of damage by diuron was 615 significant compared to control groups. It is probable that the measured level of DNA 616 breakage could have been higher if a DNA decondensation step was added to the Comet 617 protocol prior to electrophoresis.

618 The presence of DNA damage in gamete cells may dramatically reduce the success of 619 fertilization and consequently impair reproduction. Mai et al. (2013) demonstrated that sperm 620 cells in vitro-exposed to $0.04 \mu \mathrm{g} \mathrm{L}^{-1}$ of diuron had a reduced fertilization ability. A similar 621 observation was made in the sea urchin Paracentrotus lividus following exposure to $1 \mathrm{mg} \mathrm{L}^{-1}$ 622 of diuron (Manzo et al., 2006). Our study showed the transmission of DNA damage to be 623 potentially responsible for a significant decrease in the hatching rate of offspring originating 624 from diuron-exposed genitors. Moreover, it may also be involved in the developmental 625 abnormalities observed in D-stage larvae. Of note, variations were observed in the levels of 626 developmental abnormalities determined in the present study by the embryo-larval bioassay 627 versus direct sampling from the nursery tanks, probably due to differences in test conditions. 628 In the nursery tanks, the embryotoxic effect observed in the solvent control group was not 629 expected and not confirmed by the embryo-larval bioassay. Moreover, acetonitrile never 630 impacted growth and DNA integrity in both genitors and their offspring (spat) during the all 631 experiment.

632 Some phenotypic consequences have already been associated with the transmission of 633 damaged DNA during fertilization. Regarding invertebrate species, Lewis and Galloway 
634 (2009) demonstrated that in the polychaete Arenicola marina and mussel Mytilus edulis, 635 paternal exposure to genotoxins (methyl methanesulfonate and benzo(a)pyrene) resulted in 636 significant DNA damage in sperm, leading to teratogenic impacts on larval development. In 637 fish, the exposure of the three-spined stickleback spermatozoa to an alkylating agent (methyl 638 methanesulfonate) revealed a significant relationship between abnormal development and 639 sperm DNA damage (Santos et al., 2013).

640 The transmission of damaged DNA during fertilization is likely to be responsible for the 641 detection of DNA damage in the following generation. Indeed, clastogenic and aneugenic 642 effects were observed via FCM in spat from diuron-exposed genitors. In this group, 15\% of 643 analysed individuals showed DNA hypodiploidy; interestingly, this percentage is in a similar 644 range (15-22\%) to that determined in French oyster farming areas most highly-impacted by 645 summer mortality (Benabdelmouna et al., 2011). The absence of primary DNA lesions in 646 spat, as measured by the Comet assay, could be explained by the capacity of DNA repair 647 machinery to eliminate this type of lesion, whereas chromosomal damage is irreversible.

648 These results underline the good complementarity of the genotoxic approaches adopted in the 649 present study.

650 The cross-generation transmission of chromosomal abnormalities has already been 651 demonstrated in a variety of species. Hypodiploid spat have been observed in the Pacific 652 oyster following parental diuron exposure (Bouilly et al., 2007). In rainbow trout, males 653 exposed to estrogen 17-ethynylestradiol (EE2) showed high levels of aneuploid sperm, 654 strongly correlated with levels of embryonic aneuploidy (Brown et al., 2008).

655

656

\section{Conclusion}

657

In this study, the vertical transmission of DNA damage was highlighted by subjecting oyster

658 genitors to short exposures (two 7-day pulses) to diuron at environmental concentrations (0.3 659 $\mu \mathrm{g} \mathrm{L}^{-1}$ ) during gametogenesis. The presence of structural DNA lesions was demonstrated in 660 male gamete DNA using the alkaline Comet assay. Despite a loss of DNA integrity, male gametes were still efficient at fertilizing oyster oocytes. However, the transmission of 662 damaged DNA is thought to be involved in the negative impact observed on oyster 663 recruitment (decreased hatching rate, higher levels of larvae abnormalities and reduced larvae 664 growth). The parental transmission of DNA damage to the next generation was demonstrated by the detection of a high rate of DNA aneuploidy (up to 15\%) in spat from diuron-exposed 666 genitors. The analysis of POCIS showed that oysters were exposed to integrated 667 concentrations as low as 0.2 and $0.3 \mu \mathrm{g} \mathrm{L}^{-1}$. Compared to the range of concentrations 
668

669

670

671

672

673

674

675

676

677

678

679

680

681

682

683

684

685

686

687

688

689

690

691

692

693

694

695

696

697

698

699

700

701

702

703

measured in coastal waters, such observed effects could represent a threat for the reproduction and survival of wild or cultivated Pacific oyster, with high consequences on economic activities.

Investigations will be continued in order to determine whether the decrease in the DNA content observed by FCM can be explained by chromosome breaks or chromosome loss. The existence of a statistical link between the presence of genomic abnormalities induced by diuron in spat and their physiological fitness will subsequently be studied in the field, in terms of growth and performances against oyster mortality.

\section{Acknowledgments}

This work was funded by the French National Research Agency (ANR-CESA-01601). The authors are grateful to P. Phelipot and C. Yonneau for their punctual technical assistance.

\section{References}

AFNOR, 2009. Bio-indicateur de la toxicité potentielle de milieu aqueux. XP-T90-382. AFNOR, La Plaine-Saint-Denis, France, p. 19.

Aardema, M.J., Albertini, S., Arni, P., Henderson, L.M., Kirsch-Volders, M., Mackay, J.M., Sarrif, a M., Stringer, D. a, Taalman, R.D., 1998. Aneuploidy: a report of an ECETOC task force. Mutation Research 410, 3-79.

Abass, K., Reponen, P., Turpeinen, M., Jalonen, J., Pelkonen, O., 2007. Characterization of Diuron N -Demethylation by Mammalian Hepatic Microsomes and cDNA-Expressed Human Cytochrome P450 Enzymes. Drug Metabolism and Disposition 35, 1634-1641.

Akcha, F., Burgeot, T., Budzinski, H., Pfohl-Leszkowicz, A., Narbonne, J., 2000. Induction and elimination of bulky benzo[a]pyrene-related DNA adducts and 8-oxodGuo in mussels Mytilus galloprovincialis exposed in vivo to B[a]P-contaminated feed. Marine Ecology Progress Series 205, 195-206.

Akcha, F., Vincent Hubert, F., Pfhol-Leszkowicz, A., 2003. Potential value of the Comet assay and DNA adduct measurement in dab (Limanda limanda) for assessment of in situ exposure to genotoxic compounds. Mutation Research 534, 21-32.

Akcha, F., Tanguy, A., Leday, G., Pelluhet, L., Budzinski, H., \& Chiffoleau, J.-F., 2004. Measurement of DNA single-strand breaks in gill and hemolymph cells of mussels, Mytilus sp., collected on the French Atlantic Coast. Marine Environmental Research 58, 753-756.

Akcha, F., Spagnol, C., Rouxel, J., 2012. Genotoxicity of diuron and glyphosate in oyster spermatozoa and embryos. Aquatic Toxicology 106-107, 104-113. 
Alvarez, D. a, Petty, J.D., Huckins, J.N., Jones-Lepp, T.L., Getting, D.T., Goddard, J.P., Manahan, S.E., 2004. Development of a passive, in situ, integrative sampler for hydrophilic organic contaminants in aquatic environments. Environmental Toxicology and Chemistry / SETAC 23, 1640-1648.

Barsiene, J., Schiedek, D., Rybakovas, A., Syvokiene, J., Kopecka, J., Förlin, L., 2006. Cytogenetic and cytotoxic effects in gill cells of the blue mussel Mytilus spp. from different zones of the Baltic Sea. Marine Pollution Bulletin 53, 469-78.

Bauchinger, M., Kulka, U., Schmid, E., 1989. Cytogenetic effects of 3,4-dichloroaniline in human lymphocytes and V79 Chinese hamster cells. Mutation Research Letters 226, 197-202.

Benabdelmouna, A., Ollier, S., Maurouard, E., D’Amico, F., Seugnet, J.L., Grizon, J., 2011. Niveau de ploïdie des naissains d'huître creuse captés dans les bassins de Marennes Oléron, Baie de Bourgneuf et Arcachon. Réseau Biovigilance, campagne 2011. http://archimer.ifremer.fr/doc/00107/21837/19427.pdf

Bickham, J.W., Hanks, B.G., Smolen, M.J., Lamb, T., Gibbons, J.W., 1988. Flow cytometric analysis of the effects of low-level radiation exposure on natural populations of slider turtles (Pseudemys scripta). Archives of Environmental Contamination and Toxicology 17, 837-841.

Bickham, J.W., 1990. Flow Cytometry as a Technique to Monitor the Effects of Environmental Genotoxins on Wildlife Populations. In Situ Evaluation of Biological Hazards of Environmental Pollutants Environmental Science Research 38, 97-108.

Bickham, J.W., Sawin, V.L., Burton, D.W., McBee, K., 1992. Flow-cytometric analysis of the effects of triethylenemelamine on somatic and testicular tissues of the rat. Cytometry 13, 368-373.

Bihari, N., Mičić, M., Batel, R., Zahn, R.K., 2003. Flow cytometric detection of DNA cell cycle alterations in hemocytes of mussels (Mytilus galloprovincialis) off the Adriatic coast, Croatia. Aquatic Toxicology 64, 121-129.

Bony, S., Gillet, C., Bouchez, A., Margoum, C., Devaux, A., 2008. Genotoxic pressure of vineyard pesticides in fish: Field and mesocosm surveys. Aquatic Toxicology 89, 197203.

Bouilly, K., 2004. Impact de facteurs environnementaux sur l'aneuploïdie chez l'huître creuse, Crassostrea gigas, dans le bassin de Marennes-Oléron. Thèse de Doctorat. Université de la Rochelle.

Bouilly, K., Bonnard, M., Gagnaire, B., Renault, T., Lapègue, S., 2007. Impact of diuron on aneuploidy and hemocyte parameters in Pacific oyster, Crassostrea gigas. Archives of Environmental Contamination and Toxicology 52, 58-63.

Bouilly, K., Leitão, A., McCombie, H., Lapègue, S., 2003. Impact of atrazine on aneuploidy in Pacific oysters, Crassostrea gigas. Environmental Toxicology and Chemistry / SETAC 22, 219-23. 
Bouilly, K., McCombie, H., Leitao, A., Lapègue, S., 2004. Persistence of atrazine impact on aneuploidy in Pacific oysters, Crassostrea gigas. Marine Biology 145, 699-705.

Brown, K.H., Schultz, I.R., Cloud, J.G., Nagler, J.J., 2008. Aneuploid sperm formation in rainbow trout exposed to the environmental estrogen $17\{$ alpha $\}$-ethynylestradiol. Proceedings of the National Academy of Sciences of the United States of America 105, 19786-19791.

Buisson, S., Bouchart, V., Guerlet, E., Malas, J.P., Costil, K., 2008. Level of contamination and impact of pesticides in cupped oyster, Crassostrea gigas, reared in a shellfish production area in Normandy (France). Journal of Environmental Science and Health. Part. B, Pesticides, Food contaminants, and Agricultural wastes 43, 655-664.

Burgeot, T., Gagnaire, B., Renault, T., Haure, J., Moraga, D., David, E., Boutet, I., Sauriau, P.G., Malet, N., Bouchet, V., Le Roux, A., Lapègue, S., Bouilly, K., Le Moullac, G., Arzul, G., Knoery, J., Quiniou, F., Barcher, C., Soletchnick, P., 2008. Oyster summer morality risks associated with environmental stress., in: Samain, J.F., McCom- Bie, H. (Eds.), Summer Mortality of Pacific Oyster Crassostrea Gigas. The Morest Project. Éd. Ifremer/Quæ. pp. 107-151.

Caquet, T., Roucaute, M., Mazzella, N., Delmas, F., Madigou, C., Farcy, E., Burgeot, T., Allenou, J.-P., Gabellec, R., 2013. Risk assessment of herbicides and booster biocides along estuarine continuums in the Bay of Vilaine area (Brittany, France). Environmental Science and Pollution Research 20, 651-666.

CNC (Comité National de la Conchyliculture), 2013. http://www.cnc-france.com/LaProduction-francaise.aspx (accessed July 2013).

Cukurcam, S., Sun, F., Betzendahl, I., Adler, I.-D., Eichenlaub-Ritter, U., 2004. Trichlorfon predisposes to aneuploidy and interferes with spindle formation in in vitro maturing mouse oocytes. Mutation Research 564, 165-178.

Dallas, L.J., Bean, T.P., Turner, A., Lyons, B.P., Jha, A.N., 2013. Oxidative DNA damage may not mediate Ni-induced genotoxicity in marine mussels: assessment of genotoxic biomarkers and transcriptional responses of key stress genes. Mutation Research 754, $22-31$.

Deaven, L.L., 1982. Application of flow cytometry to cytogenetic testing of environmental mutagens. In Hsu, T.C. ed. Cytogenetic assays of environmental mutagens, 325-51. Totowa: Allanheld, Osmun and Company, Publishers.

Devaux, A., Fiat, L., Gillet, C., Bony, S., 2011. Reproduction impairment following paternal genotoxin exposure in brown trout (Salmo trutta) and Arctic charr (Salvelinus alpinus). Aquatic Toxicology 101, 405-411.

Dich, J., Zahm, S.H., Hanberg, a, Adami, H.O., 1997. Pesticides and Cancer. Cancer Causes \& Control 8, 420-443.

Dixon, D.R., Pruski, A.M., Dixon, L.R.J., Jha, A.N., 2002. Marine invertebrate ecogenotoxicology: a methodological overview. Mutagenesis 17, 495-507. 
Doherty, a T., Ellard, S., Parry, E.M., Parry, J.M., 1996. A study of the aneugenic activity of trichlorfon detected by centromere-specific probes in human lymphoblastoid cell lines. Mutation Research 372, 221-31.

Favret, K.P., Lynn, J.W., 2010. Flow-cytometric analyses of viability biomarkers in pesticideexposed sperm of three aquatic invertebrates. Archives of Environmental Contamination and Toxicology 58, 973-84.

Gagnaire, B., Gay, M., Huvet, A., Daniel, J.-Y., Saulnier, D., Renault, T., 2007. Combination of a pesticide exposure and a bacterial challenge: in vivo effects on immune response of Pacific oyster, Crassostrea gigas (Thunberg). Aquatic Toxicology 84, 92-102.

Gagnaire, B., Thomas-Guyon, H., Burgeot, T., Renault, T., 2006. Pollutant effects on Pacific oyster, Crassostrea gigas (Thunberg), hemocytes: screening of 23 molecules using flow cytometry. Cell Biology and Toxicology 22, 1-14.

Goanvec, C., Theron, M., Lacoue-Labarthe, T., Poirier, E., Guyomarch, J., Le-Floch, S., Laroche, J., Nonnotte, L., Nonnotte, G., 2008. Flow cytometry for the evaluation of chromosomal damage in turbot Psetta maxima (L.) exposed to the dissolved fraction of heavy fuel oil in sea water: a comparison with classical biomarkers. Journal of Fish Biology 73, 395-413.

Hagger, J. a., Depledge, M.H., Oehlmann, J., Jobling, S., Galloway, T.S., 2005. Is There a Causal Association between Genotoxicity and the Imposex Effect? Environmental Health Perspectives 114, 20-26.

Hagmar, L., Bonassi, S., Strömberg, U., Brogger, A., Knudsen, L.E., Norppa, H., Reuterwall, C., 1998. Chromosomal Aberrations in Lymphocytes Predict Human Cancer: A Report from the European Study Group on Cytogenetic Biomarkers and Health (ESCH). Cancer Research 58, 4117-4121.

His, E., Heyvang, I., Geffard, O., De Montaudouin, X., 1999. A comparison between oyster (Crassostrea gigas) and sea urchin (Paracentrotus lividus) larval bioassays for toxicological studies. Water Research 33, 1706-1718.

Hodge, H.C., Downs, W.L., Panner, B.S., Smith, D.W., Maynard, E.A., Jr., J.W.C., Rhodes, R.C., 1967. Oral toxicity and metabolism of diuron (N-(3,4-dichlorophenyl)-N', $\mathrm{N}^{\prime}-$ dimethylurea) in rats and dogs. Food and Cosmetics Toxicology 5, 513-531.

Jacquet, F., Butault, J.-P., Guichard, L., 2011. An economic analysis of the possibility of reducing pesticides in French field crops. Ecological Economics 70, 1638-1648.

Jung, D., Matson, C.W., Collins, L.B., Laban, G., Stapleton, H.M., Bickham, J.W., Swenberg, J. a, Di Giulio, R.T., 2011. Genotoxicity in Atlantic killifish (Fundulus heteroclitus) from a PAH-contaminated Superfund site on the Elizabeth River, Virginia. Ecotoxicology 20, 1890-9.

Kashida, Y., Sasaki, Y. F., Ohsawa, K., Yokohama, N., Takahashi, A., Watanabe, T., Mitsumori, K., 2002. Mechanistic study on flumequine hepatocarcinogenicity focusing on DNA damage in mice. Toxicological Sciences 69, 317-321. 
Labreuche, Y., 2006. Caractérisation de la virulence d'une souche de Vibrio aestuarianus , pathogène de l'huître Crassostrea gigas. Thèse de Doctorat. Université de Bretagne occidentale - Brest.

Lacaze, E., Geffard, O., Goyet, D., Bony, S., Devaux, A., 2011. Linking genotoxic responses in Gammarus fossarum germ cells with reproduction impairment, using the Comet assay. Environmental Research 111, 626-634.

Lamb, T., Bickham, J.W., Gibbons, J.W., Smolen, M.J., McDowell, S., 1991. Genetic damage in a population of Slider Turtles (Trachemys scripta) inhabiting a radioactive reservoir. Archives of Environmental Contamination and Toxicology 20, 138-142.

Lamoree, M.H., Swart, C.P., Van der Horst, A., Van Hattum, B., 2002. Determination of diuron and the antifouling paint biocide Irgarol 1051 in Dutch marinas and coastal waters. Journal of Chromatography A 970, 183-190.

Landa, G., Parrella, L., Avagliano, S., Ansanelli, G., Maiello, E., Cremisini, C., 2009. Assessment of the Potential Ecological Risks Posed by Antifouling Booster Biocides to the Marine Ecosystem of the Gulf of Napoli (Italy). Water, Air, and Soil Pollution 200, 305-321.

Leitao, A., Boudry, P., Thiriot-quievreux, C., 2001. Negative correlation between aneuploidy and growth in the Pacific oyster, Crassostrea gigas: ten years of evidence. Aquaculture 193, 39-48.

Lewis, C., Ford, A.T., 2012. Infertility in male aquatic invertebrates: a review. Aquatic Toxicology 120-121, 79-89.

Lewis, C., Galloway, T., 2009. Reproductive consequences of paternal genotoxin exposure in marine invertebrates. Environmental Science \& Technology 43, 928-33.

Lowcock, L.A., Sharbel, T.F., Bonin, J., Ouellet, M., Rodrigue, J., DesGranges, J.-L., 1997. Flow cytometric assay for in vivo genotoxic effects of pesticides in Green frogs (Rana clamitans). Aquatic Toxicology 38, 241-255.

Luna-Acosta, A., Renault, T., Thomas-Guyon, H., Faury, N., Saulnier, D., Budzinski, H., Le Menach, K., Pardon, P., Fruitier-Arnaudin, I., Bustamante, P., 2012. Detection of early effects of a single herbicide (diuron) and a mix of herbicides and pharmaceuticals (diuron, isoproturon, ibuprofen) on immunological parameters of Pacific oyster (Crassostrea gigas) spat. Chemosphere 87, 1335-40.

Mai, H., Morin, B., Budzinski, H., Cachot, J., 2013. Environmental concentrations of irgarol, diuron and S-metolachlor induce deleterious effects on gametes and embryos of the Pacific oyster, Crassostrea gigas. Marine Environmental Research 89, 1-8.

Manzo, S., Buono, S., Cremisini, C., 2006. Toxic effects of irgarol and diuron on sea urchin Paracentrotus lividus early development, fertilization, and offspring quality. Archives of Environmental Contamination and Toxicology 51, 61-8. 
Marcheselli, M., Azzoni, P., Mauri, M., 2011. Novel antifouling agent-zinc pyrithione: stress induction and genotoxicity to the marine mussel Mytilus galloprovincialis. Aquatic Toxicology 102, 39-47.

Mateuca, R., Lombaert, N., Aka, P. V, Decordier, I., Kirsch-Volders, M., 2006. Chromosomal changes: induction, detection methods and applicability in human biomonitoring. Biochimie 88, 1515-31.

Mattiuzzo, M., Fiore, M., Ricordy, R., Degrassi, F., 2006. Aneuploidy-inducing capacity of two widely used pesticides. Carcinogenesis $27,2511-8$.

Mazzella, N., Lissalde, S., Moreira, S., Delmas, F., Mazellier, P., Huckins, J.N., 2010. Evaluation of the use of performance reference compounds in an Oasis-HLB adsorbent based passive sampler for improving water concentration estimates of polar herbicides in freshwater. Environmental Science \& Technology 44, 1713-1719.

Morris, I. D., Ilott, S., Dixon, L., \& Brison, D. R., 2002. The spectrum of DNA damage in human sperm assessed by single cell gel electrophoresis (Comet assay) and its relationship to fertilization and embryo development. Human Reproduction 17, 990-998.

Munaron, D., 2004. Étude des apports en herbicides et en nutriments par la Charente: Modélisation de la dispersion de l'atrazine dans le bassin de Marennes-Oléron. Thèse de Doctorat. Université Paris 6 Pierre et Marie Curie.

Munaron, D., Scribe, P., Dubernet, J.F., Kantin, R., Vanhoutte, A., Fillon, A., Bacher, C., 2003. Estimation of herbicide inputs in a sensitive area on the Atlantic coast: MarennesOleron Bay (France), in: DelRe, AAM and Capri, E and Padovani, L and Trevisan, M. (Ed.), Pesticides in Air, Plant, Soil and Water System. pp. 717-726.

Munaron, D., Tapie, N., Budzinski, H., Andral, B., Gonzalez, J.-L., 2012. Pharmaceuticals, alkylphenols and pesticides in Mediterranean coastal waters: Results from a pilot survey using passive samplers. Estuarine, Coastal and Shelf Science 114, 82-92.

Nebeker, A. V, Schuytema, G.S., 1998. Chronic Effects of the Herbicide Diuron on Freshwater Cladocerans, Amphipods, Midges, Minnows, Worms, and Snails. Archives of Environmental Contamination and Toxicology 35, 441-446.

Okamura, H., Aoyama, I., Ono, Y., Nishida, T., 2003. Antifouling herbicides in the coastal waters of western Japan. Marine Pollution Bulletin 47, 59-67.

Osano, O., Admiraal, W., Klamer, H.J.C., Pastor, D., Bleeker, E. a J., 2002. Comparative toxic and genotoxic effects of chloroacetanilides, formamidines and their degradation products on Vibrio fischeri and Chironomus riparius. Environmental Pollution 119, 195202.

Otto, F.J., Oldiges, H., Göhde, W., Jain, V.K., 1981. Flow cytometric measurement of nuclear DNA content variations as a potential in vivo mutagenicity test. Cytometry 2, 189-91. 
Quiniou, F., His, E., Delesmont, R., Caisey, X., 2005. Bio-indicateur de la toxicité potentielle de milieux aqueux: bio-essai «Développement embryo-larvaire de bivalve ». In : Méthodes d'analyses en Milieu Marin. Ifremer/Quae

Rigos, G., Tyrpenou, A., Nengas, I., \& Alexis, M., 2002. A pharmacokinetic study of flumequine in sea bass, Dicentrarchus labrax (L.), after a single intravascular injection. Journal of Fish Diseases 25, 101-105.

Samain, J.F., Dégremont, L., Soletchnik, P., Haure, J., Bédier, E., Ropert, M., Moal, J., Huvet, A., Bacca, A., Van Wormhoudt, A., Delaporte, M., Costil, K., Pouvreau, S., Lambert, C., Boulo, V., Soudant, P., Nicolas, J., Le Roux, F., Renault, T., Gagnaire, B., Geret, F., Boutet, I., Burgeot, T., Boudry, P., 2007. Genetically based resistance to summer mortality in the Pacific oyster (Crassostrea gigas) and its relationship with physiological , immunological characteristics and infection processes. Aquaculture 268, 227-243.

Sánchez-Rodríguez, A., Sosa-Ferrera, Z., Santana-del Pino, A., Santana-Rodríguez, J.J., 2011. Probabilistic risk assessment of common booster biocides in surface waters of the harbours of Gran Canaria (Spain). Marine Pollution Bulletin 62, 985-991.

Santos, R., Palos-Ladeiro, M., Besnard, a, Porcher, J.M., Bony, S., Sanchez, W., Devaux, a, 2013. Relationship between DNA damage in sperm after ex vivo exposure and abnormal embryo development in the progeny of the three-spined stickleback. Reproductive Toxicology 36, 6-11.

Schuytema, G.S., Nebeker, A. V, 1998. Comparative Toxicity of Diuron on Survival and Growth of Pacific Treefrog, Bullfrog, Red-Legged Frog, and African Clawed Frog Embryos and Tadpoles. Archives of Environmental Contamination and Toxicology 34, 370-376.

SOeS (Service de l'Observation et des Statistiques), 2011. Environnement Littoral et marin; Références. Colas S, 165 pp. http://www.onml.fr/uploads/media/references_littoralchap.V.pdf (accessed July 2013)

Speit, G., Vasquez, M., Hartmann, A., 2009. The Comet assay as an indicator test for germ cell genotoxicity. Mutation Research 681, 3-12.

Srogi, K., 2007. Monitoring of environmental exposure to polycyclic aromatic hydrocarbons: a review. Environmental Chemistry Letters 5, 169-195.

Stachowski-haberkorn, Sabine; Quiniou, Françoise; Nedelec, Morgane; Robert, René; Limon, Gwendolina; De la Broise, D., 2008. In-situ microcosms, a tool for assessment of pesticide impacts on oyster spat (Crassostrea gigas). Ecotoxicology 17, 235-245.

Suda, J., Krahulcova, A., Travnicek, P., Krahulec, F., 2006. Ploidy level versus DNA ploidy level: an appeal for consistent terminology. Taxon 55, 447-450.

Sun, F.Y., Schmid, T.E., Schmid, E., Baumgartner, a, Adler, I.D., 2000. Trichlorfon induces spindle disturbances in V79 cells and aneuploidy in male mouse germ cells. Mutagenesis $15,17-24$. 
T. Lamb, J. Bickham, T. Barret Lyne, J.W.G., 1995. The slider turtle as an environmental sentinel: multiple tissue assays using flow cytometric analysis. Ecotoxicology 4, 5-13.

Tapie, N., Devier, M.H., Soulier, C., Creusot, N., Le Menach, K., Aït-Aïssa, S., Vrana, B., Budzinski, H., 2011. Passive samplers for chemical substance monitoring and associated toxicity assessment in water. Water Science \& Technology 63, 2418-2426.

Theodorakis, C.W., Bickham, J.W., Donnelly, K.C., McDonald, T.J., Willink, P.W., 2012. DNA damage in cichlids from an oil production facility in Guatemala. Ecotoxicology 21, 496-511.

Thomas, K. V, Fileman, T.W., Readman, J.W., Waldock, M.J., 2001. Antifouling Paint Booster Biocides in the UK Coastal Environment and Potential Risks of Biological Effects. Marine Pollution Bulletin 42, 677-688.

Thomas, K. V, McHugh, M., Waldock, M., 2002. Antifouling paint booster biocides in UK coastal waters: inputs, occurrence and environmental fate. The Science of the Total Environment 293, 117-27.

Tian, Y., Ishikawa, H., Yamauchi, T., 2000. Analysis of cytogenetic and developmental effects on pre-implantation, mid-gestation and near-term mouse embryos after treatment with trichlorfon during zygote stage. Mutation Research 471, 37-44.

UIPP (Union des Industries de la Protection des Plantes), 2012. Rapport d'activité UIPP 2011/2012, 43 pp. http://www.uipp.org/Actualites/Legislation-etreglementation/Actualite-francaise/Rapport-d-activite-UIPP-2011-2012-consultable-enligne (accessed July 2013).

UNEP (United Nations Environment programme) http://www.unep.org/regionalseas/issues/landactivities/default.asp (accessed July 2013).

Van Boven, M., Laruelle, L., Daenens, P., 1990. HPLC analysis of diuron and metabolites in blood and urine. Journal of Analytical Toxicology 14, 231-234.

Verheij, E.R., der Greef, J., La Vos, G.F., der Pol, W., Niessen, W.M.A., 1989. Identification of diuron and four of its metabolites in human postmortem plasma and urine by LC/MS with a moving-belt interface. Journal of Analytical Toxicology 13, 8-12.

Vrana, B., Allan, I.J., Greenwood, R., Mills, G. a., Dominiak, E., Svensson, K., Knutsson, J., Morrison, G., 2005. Passive sampling techniques for monitoring pollutants in water. Trends in Analytical Chemistry 24, 845-868.

Wessel, N., Rousseau, S., Caisey, X., Quiniou, F., Akcha, F., 2007. Investigating the relationship between embryotoxic and genotoxic effects of benzo[a]pyrene, 17alphaethinylestradiol and endosulfan on Crassostrea gigas embryos. Aquatic Toxicology 85, 133-42.

Wilson, J.T., Dixon, D.R., Dixon, L.R.J., 2002. Numerical chromosomal aberrations in the early life-history stages of a marine tubeworm, Pomatoceros lamarckii (Polychaeta: Serpulidae). Aquatic Toxicology 59, 163-75. 
Fig. 1. General diagram of the experiment (black arrows represent different sampling points)

Fig. 2. Effect of diuron exposure on genitor weight at the end of the first (Tep1) and second (Tep2) exposure pulses. Data that do not share the same letter are significantly different.

Fig. 3. Effect of diuron exposure on levels of DNA strand breaks in genitor hemocytes at the end of the first (Tep1) and second (Tep2) exposure pulses. Data that do not share the same letter are significantly different.

Fig. 4. Effect of parental diuron-exposure on levels of DNA strand breaks in spermatozoa. Asterisks indicate the statistical differences observed between control and exposed groups. $\left.{ }^{*}\right) \mathrm{p}<0.05,\left({ }^{* *}\right) \mathrm{p}<$ $0.01,(* * *) \mathrm{p}<0.001$.

Fig. 5. Effects of parental diuron-exposure on offspring. Percentages of hatching rate (A), abnormal larvae $24 \mathrm{~h}$ post fertilization (B) and size of larvae until metamorphosis (C). Asterisks indicate the statistical differences observed between control and exposed groups. $\left(^{*}\right) \mathrm{p}<0.05,\left({ }^{* *}\right) \mathrm{p}<0.01,(* * *)$ $\mathrm{p}<0.001$.

Fig. 6. Effect of parental diuron-exposure on the level of DNA strand breaks in spat hemocytes. Asterisks indicate the statistical differences observed between control and exposed groups. $\left.{ }^{*}\right) \mathrm{p}<$ $0.05,(* *) \mathrm{p}<0.01,(* * *) \mathrm{p}<0.001$.

Fig. 7. Levels of chromosomal damage in spat from controls and diuron-exposed genitors, indicated by coefficient of variation (A) and DNA index (B) measured by flow cytometry. Asterisks indicate the statistical differences observed between control and exposed groups. $(*) p<0.05,(* *) p<0.01,(* * *)$ 998 
Table 1

999 Examples of diuron concentrations detected in coastal waters/estuaries in different parts of the 1000 World and France

1001

\begin{tabular}{|c|c|c|}
\hline Location & Concentration $\left(\mu \mathrm{g} \mathrm{L}^{-1}\right)$ & Reference \\
\hline \multicolumn{3}{|l|}{ World } \\
\hline Spain & $0.02-0.20$ & Sánchez-Rodríguez et al., 2011 \\
\hline Italy & $0.01-1.38$ & Landa et al., 2009 \\
\hline Japan & $0.03-3.05$ & Okamura et al., 2003 \\
\hline The Netherlands & $0.09-1.13$ & Lamoree et al., 2002 \\
\hline United Kingdom & $0.01-6.74$ & Thomas et al., 2001 \\
\hline \multicolumn{3}{|l|}{ France } \\
\hline Bay of Vilaine & $0.44-0.78$ & Caquet et al., 2013 \\
\hline M editerranean coastal waters & 0.33 & M unaron et al., 2012 \\
\hline Bay of Veys & $0.02-0.254$ & Buisson et al., 2008 \\
\hline Charente estuary & 0.51 & Munaron, 2004 \\
\hline
\end{tabular}

1002

1003

1004 
1004

1005

1006

1007

\begin{tabular}{|c|c|c|c|c|}
\hline $\begin{array}{l}\text { Development } \\
\text { stage }\end{array}$ & Sampling point & Tissue/ Fluid & $\begin{array}{c}\text { Number of } \\
\text { individuals/ experimental } \\
\text { group }\end{array}$ & Type of analysis \\
\hline \multirow{10}{*}{ Genitors } & & Gills & 60 & Flow cytometry \\
\hline & T0 & Hemolymph & 30 & Comet assay \\
\hline & & all & 30 & Growth \\
\hline & & Gills & 60 & Flow cytometry \\
\hline & Tep1 & Hemolymph & 30 & Comet assay \\
\hline & & all & 30 & Growth \\
\hline & & Gills & 60 & Flow cytometry \\
\hline & Tep2 & Hemolymph & 30 & Comet assay \\
\hline & & all & 30 & Growth \\
\hline & Spawning & Spermatozoa & Pool & Comet assay \\
\hline D-larvae & $\begin{array}{l}\text { 24h post- } \\
\text { fertilization }\end{array}$ & 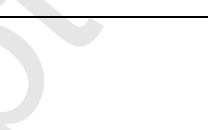 & 100 & Larval abnormalities \\
\hline \multirow[t]{2}{*}{ Spat } & 7 months & Gills & 150 & Flow cytometry \\
\hline & & Hemolymph & 30 & Comet assay \\
\hline
\end{tabular}

Table 2

Number of individuals and type of tissue/fluid sampled for each type of chemical and biological analysis 


\section{Table 3}

1011 Chemicals detected in the seawater used at the experimental hatchery and their concentrations in 1012 POCIS in $\mathrm{ng} \mathrm{g}^{-1}$ and $\mathrm{ng} \mathrm{L}^{-1}$ with and without PRC. Compounds never detected were not reported here 1013 (nd: not detected).

\begin{tabular}{|c|c|c|c|c|c|c|}
\hline \multirow[b]{2}{*}{$\begin{array}{ll}\text { Immersion } & \text { period } \\
\text { (day/month) } & \end{array}$} & \multicolumn{2}{|c|}{ Data in $\mathrm{ng} \mathrm{g}^{-1}$} & \multicolumn{2}{|c|}{$\begin{array}{c}\text { Data in } \mathrm{ng} \mathrm{L}^{-1} \\
\text { Rs low condition without } \\
\text { PRC }\end{array}$} & \multicolumn{2}{|c|}{$\begin{array}{l}\text { Data } \mathrm{ng} \mathrm{L}^{-1} \\
\text { Rs with PRC }\end{array}$} \\
\hline & $28 / 02-28 / 03$ & $28 / 03-10 / 05$ & $28 / 02-28 / 03$ & $28 / 03-10 / 05$ & $28 / 02-28 / 03$ & $28 / 03-10 / 05$ \\
\hline Immersion time (day) & 29 & 43 & 29 & 43 & 29 & 43 \\
\hline Phase weight (g) & 0.17 & 0.19 & 0.17 & 0.19 & 0.17 & 0.19 \\
\hline \multicolumn{7}{|l|}{ Pesticide list } \\
\hline Acetochlor & nd & 9.06 & nd & 0.42 & 0 & 0.95 \\
\hline Acetochlor ESA & 46.07 & 47.06 & 6.35 & 4.38 & 11.65 & 8.03 \\
\hline Atrazine & 10.01 & 11.19 & 0.43 & 0.33 & 2.53 & 1.91 \\
\hline Atrazine 2 hydroxy & 8.78 & 12.68 & 0.38 & 0.37 & 4.44 & 4.32 \\
\hline Carbendazime & 1.84 & 3.93 & 0.14 & 0.2 & 0.46 & 0.67 \\
\hline Carbetamide & 0.52 & 0.78 & 0.04 & 0.04 & 0.39 & 0.4 \\
\hline Carbofuran & 0.56 & 0.8 & 0.03 & 0.03 & 0.14 & 0.14 \\
\hline Chlorotoluron & 1.81 & 8.12 & - & - & 0.65 & 1.98 \\
\hline DEA & 142.99 & 14.86 & 12.33 & 0.86 & 57.09 & 4 \\
\hline Diuron & 4.25 & 5.11 & 0.27 & 0.22 & 0.77 & 0.62 \\
\hline DMSA & 2.62 & 2.78 & 0.23 & 0.16 & 0.69 & 0.49 \\
\hline DMST & 1.92 & 5.6 & 0.11 & 0.22 & 0.48 & 0.96 \\
\hline Flazasulfuron & 0.67 & 1.17 & 0.08 & 0.09 & 0.47 & 0.54 \\
\hline Hexazinon & 1.13 & 0.97 & 0.08 & 0.05 & 0.36 & 0.21 \\
\hline Isoproturon & 5.33 & 5.58 & 0.25 & 0.17 & 2.89 & 2.04 \\
\hline M etazachlor & 0.26 & 2.13 & 0.01 & 0.07 & 0.05 & 0.25 \\
\hline
\end{tabular}




\begin{tabular}{|c|c|c|c|c|c|c|}
\hline Metolachlor & 9.5 & 63.08 & 0.39 & 1.73 & 1.8 & 8.07 \\
\hline Metolachlor ESA & 95.24 & 109.78 & 10.95 & 8.51 & 34.4 & 26.75 \\
\hline M etolachlor OA & 45.85 & 50.87 & 4.52 & 3.38 & 26.76 & 20.02 \\
\hline Simazine & 1.49 & 2.57 & 0.05 & 0.06 & 0.66 & 0.77 \\
\hline $\begin{array}{l}\text { Terbutylazine } \\
\text { desethyl }\end{array}$ & nd & 3.8 & nd & 0.11 & 0 & 1.77 \\
\hline
\end{tabular}

1015

1016 


\section{Table 4}

1017 Example of derive TWA concentrations of diuron in the experimental tanks during the second 1018 herbicide pulse using $k_{u}$ value of 0.188 for diuron.

1019

1020

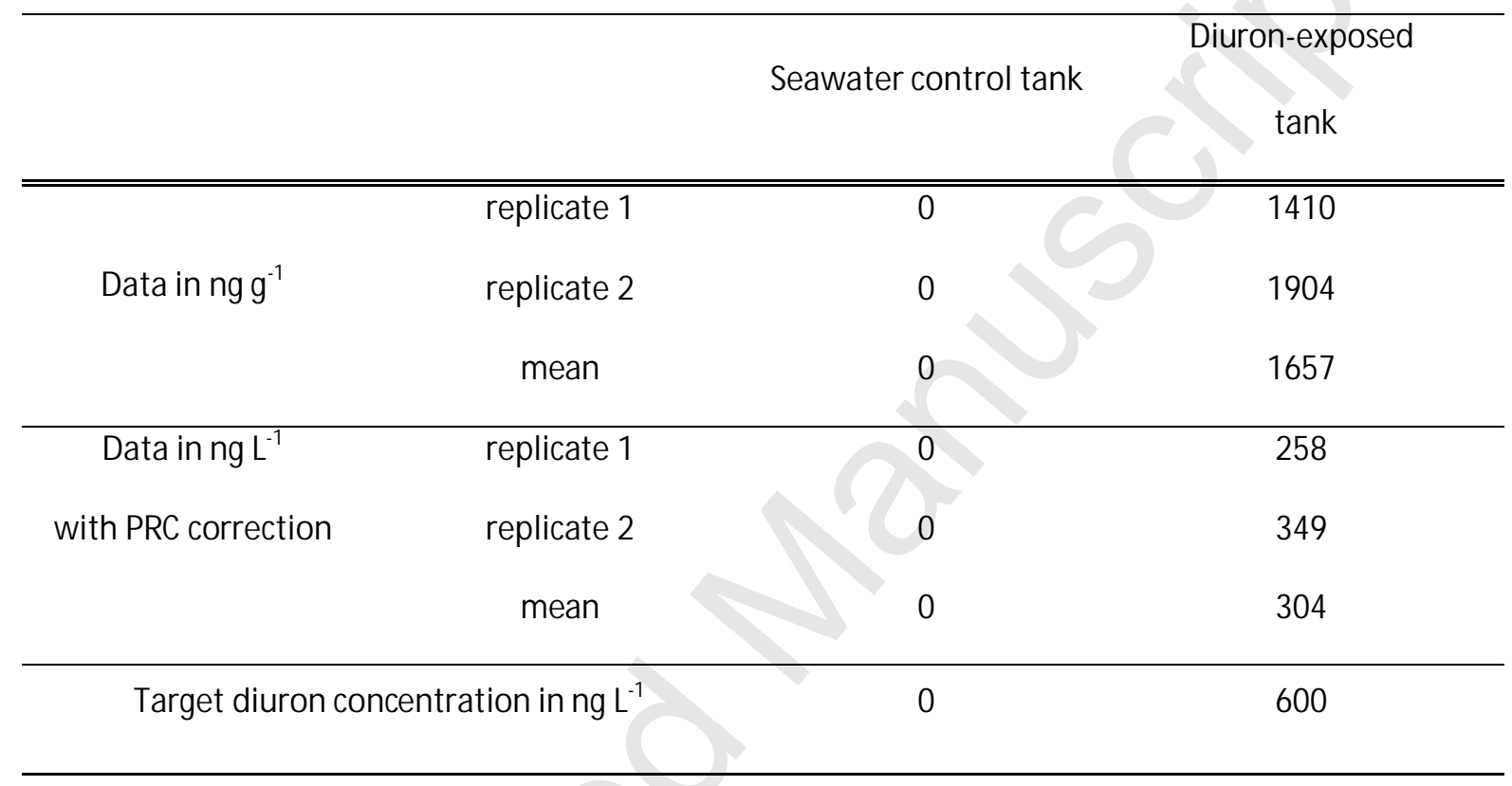

1021

1022 
1023 Coefficient of variation (CV\%), and DNA index (i.e genome size) (M ean \pm S.D.) of genitor gill tissue 1024 throughout the experiment.

1025

\begin{tabular}{cccc}
\hline Experimental group & Sampling point & CV\% & DNA index \\
\hline \hline \multirow{2}{*}{ Seawater control } & T0 & $5.162 \pm 0.452$ & $0.417 \pm 0.007$ \\
& Tep1 & $5.092 \pm 0.572$ & $0.416 \pm 0.005$ \\
& Tep2 & $5.617 \pm 0.678$ & $0.420 \pm 0.009$ \\
\hline Solvent control & T0 & $5.162 \pm 0.452$ & $0.417 \pm 0.007$ \\
& Tep1 & $4.926 \pm 0.284$ & $0.417 \pm 0.004$ \\
& Tep2 & $5.311 \pm 0.530$ & $0.419 \pm 0.009$ \\
\hline Diuron-exposed & T0 & $5.162 \pm 0.452$ & $0.417 \pm 0.007$ \\
& Tep1 & $5.212 \pm 0.435$ & $0.415 \pm 0.006$ \\
& Tep2 & $5.139 \pm 0.844$ & $0.423 \pm 0.012$ \\
\hline
\end{tabular}

1026

1027

1028 
Vertical bars denote 0,95 confidence intervals

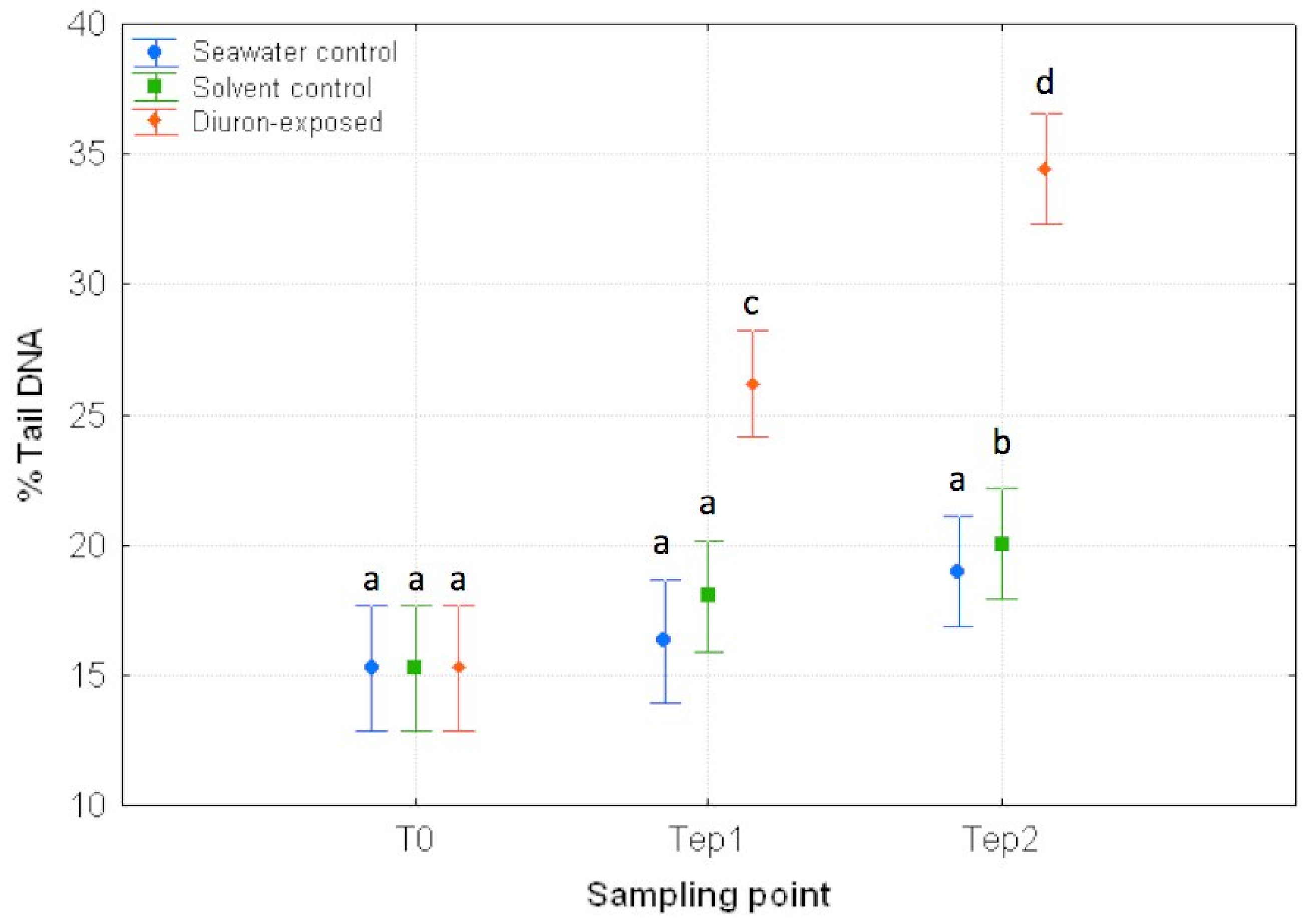



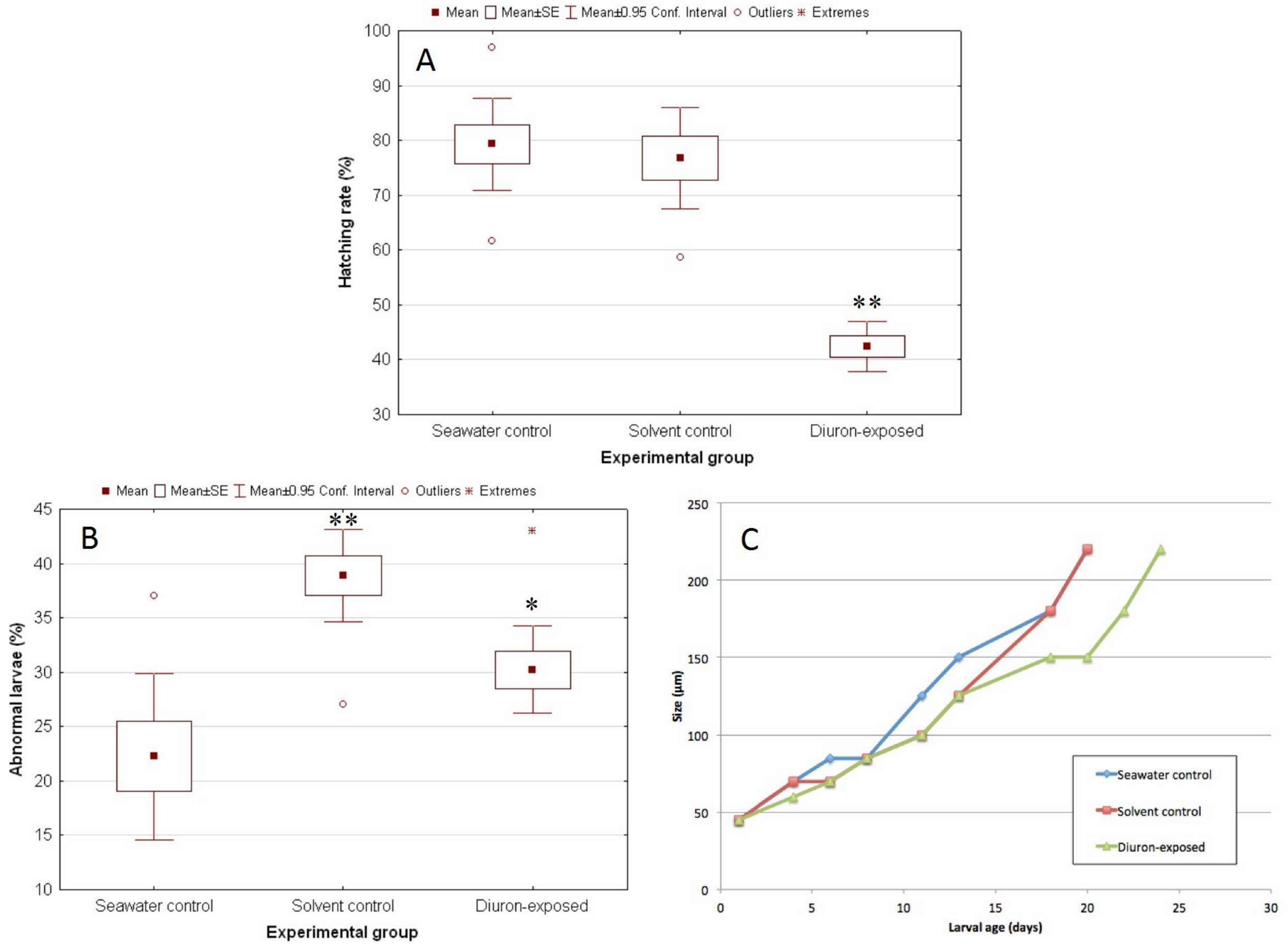


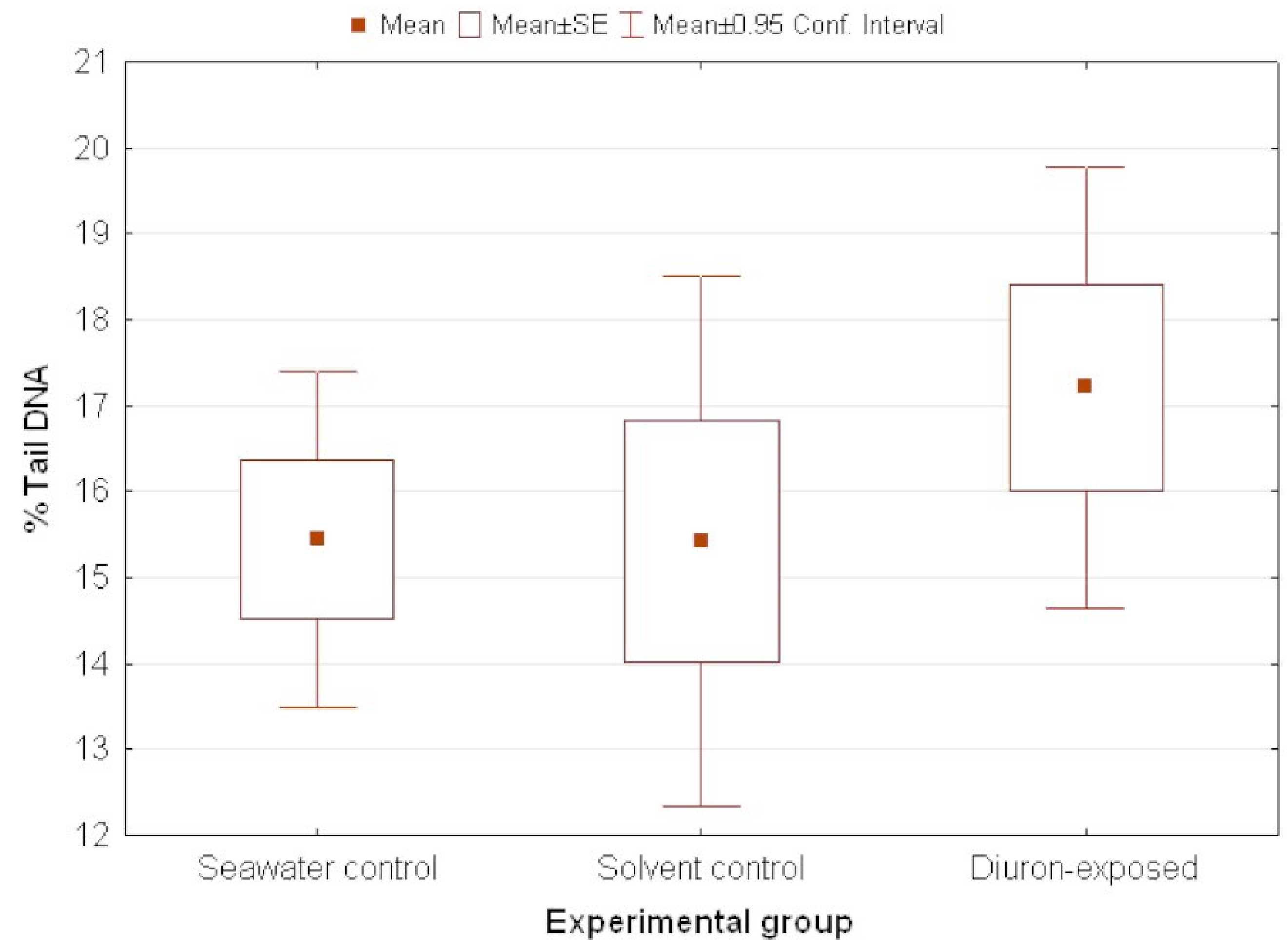



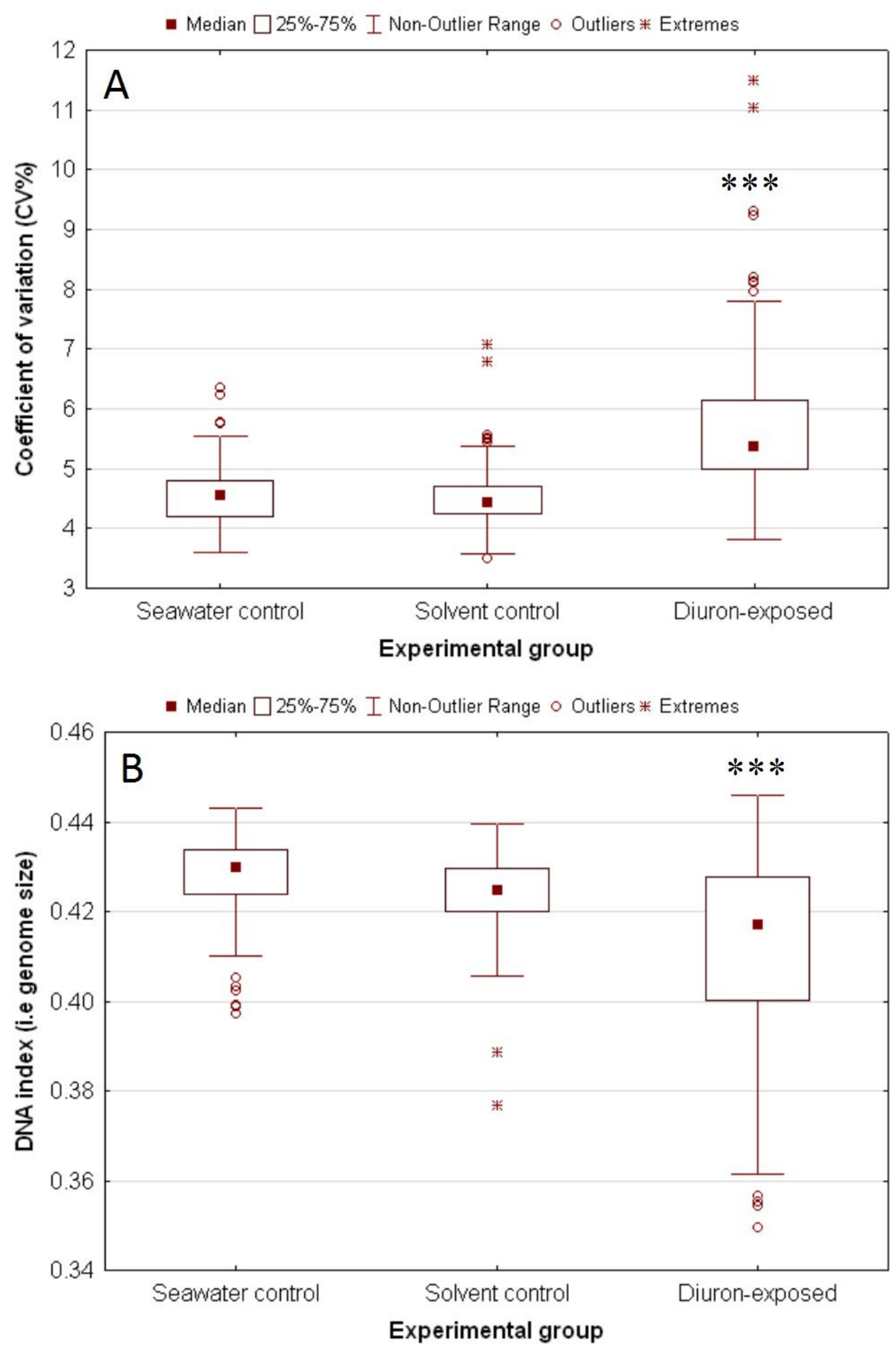

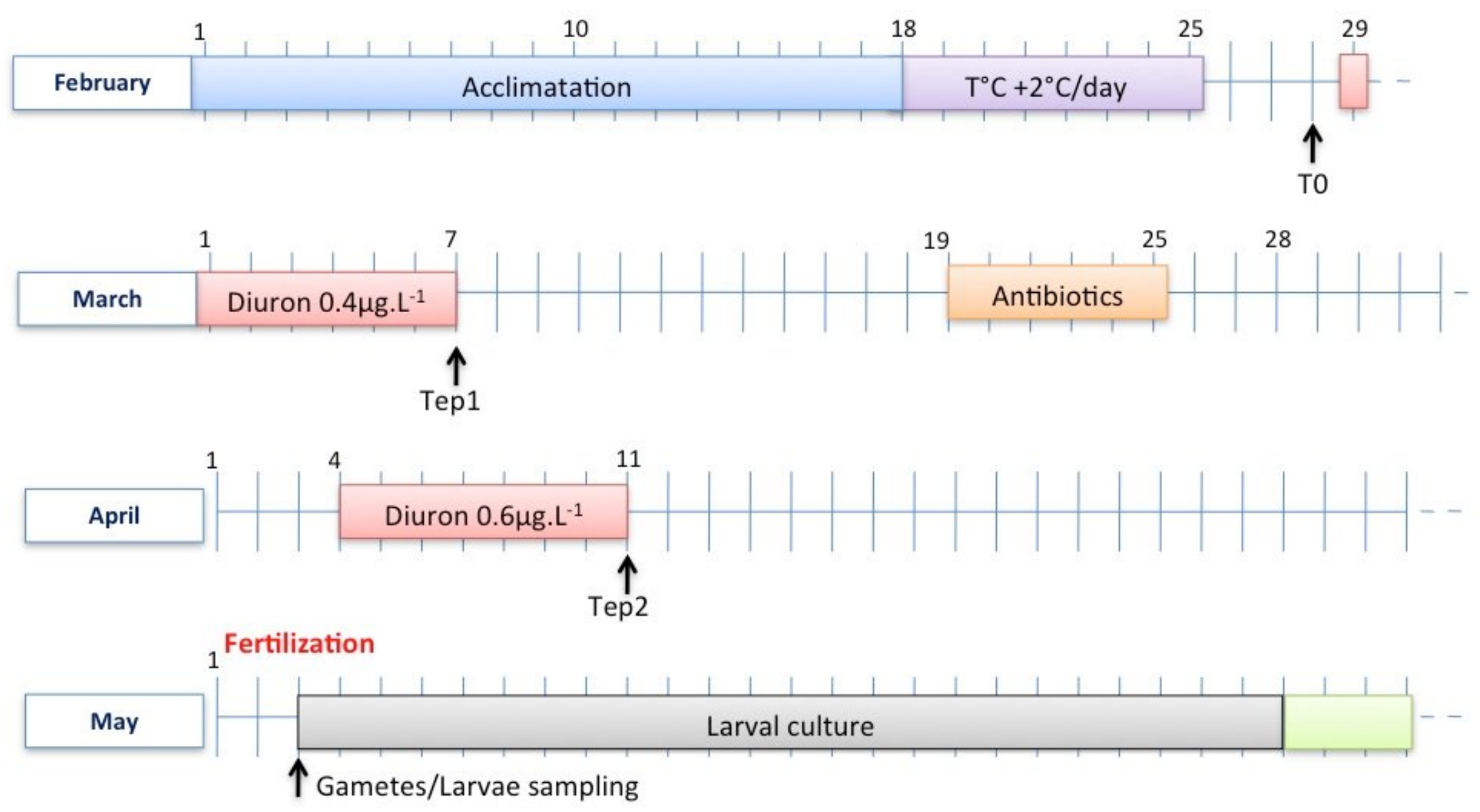

June Micronursery-Spat culture

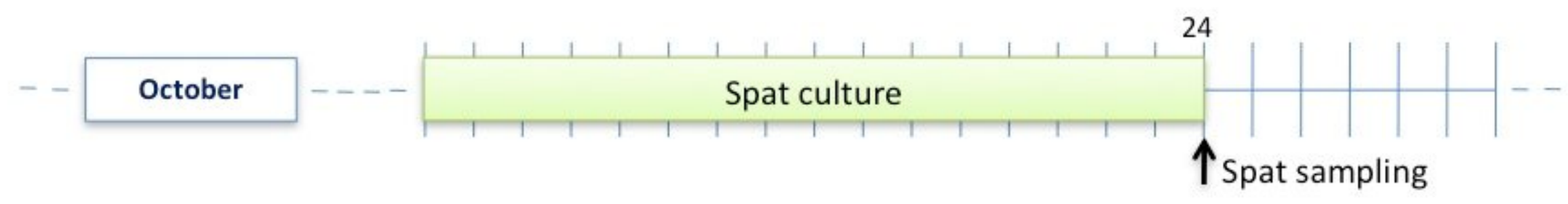




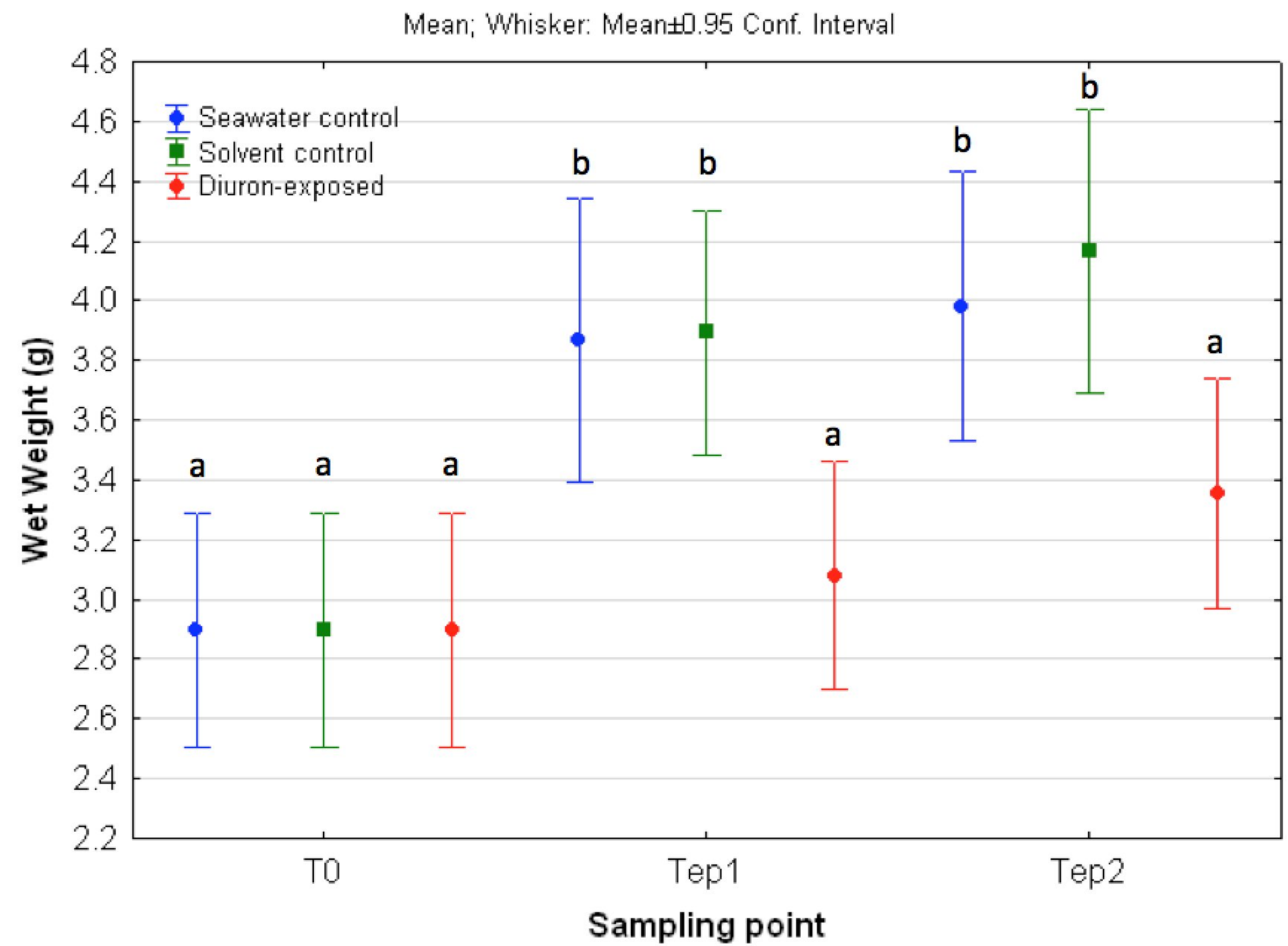

